\title{
YOUTH'S ATTITUDES TOWARD SAFETY IN CANTON OF SARAJEVO
}

\author{
Kenan Hodžić, MA \\ Faculty of Criminal Justice, Criminology and Security Studies, University of Sarajevo \\ E-mail: khodzic@fkn.unsa.ba
}

\begin{abstract}
There are a number of factors that can influence the increase in probability of occurrence, development and manifestation of violent behavior, but also increase the vulnerability of young people to various negative impacts - risk factors, as there are a number of factors that can prevent the occurrence of violent behavior in risky situations and unfavorable conditions protective factors. Their identification, analysis of the area and intensity of action, are a prerequisite for effective plans and prevention strategies, as well as treatment of already outbreaks of behavioral disorders. The authors of this paper emphasize, analyze and critically re-examine the safety of young people through the prism of the risk and protection factors involved in youth security issues. Measuring sources of vulnerability in the Sarajevo Canton educational institutions is a fundamental subject of research, while the development and implementation of mechanisms that would reduce violence among the high school population to the smallest extent possible is a complementary subject of research. The paper deals with the security issues of secondary school students in the Sarajevo Canton. In essence, continuous research into ways, procedures, and tools to raise the level of youth safety is the basis for successful building and maintaining a high quality of security management. The crucial issues that are analyzed in this paper are in the domain of timely identification and adequate response regarding, above all, the presence and frequency of violence among peers in secondary schools, forms of occurrence, the extent of violence that occurs in schools and the information that students have about this problem. but also the response of the system of protection in the school and society.
\end{abstract}

Key words: security issues, risks, secondary school, students, Canton Sarajevo.

\section{INTRODUCTION}

Safety challenges, risks and threats, especially in the context of educational institutions, cover all potential situations that deviate from the expected ones. They bring doubt into the educational process, and also the school's ability to achieve their goals and maintain a safe environment. There are a number of factors that can increase the likelihood of violent behavior and its development. They can also increase the susceptibility of young people to various negative influences - risk factors. There are also a number of factors that can prevent the occurrence of violent behavior in risky situations and adverse conditions - protection factors. Their identification, analysis and intensity of action are the prerequisites for effective prevention plans 
and strategies, as well as for the treatment of already shown behavioral disorders. The authors emphasize, analyze and critically review youth safety in the Sarajevo Canton through the prism of risk and protective factors involved in youth security issues. Measuring the sources of danger in and around secondary schools in Sarajevo Canton is the main subject of this research, while the main objective of the research is to develop and implement preventative mechanisms to minimize the sources of threat among the population. The questions that are analyzed in this paper are in the domain of timely identification and adequate response, which primarily concern the presence and frequency of threatening factors in secondary schools, the extent of school violence, information and knowledge that students have about this problem, and the response of the protection system schools and in society.

Only through continuous research on procedures and means to raise the level of youth safety can we create the basis for successful construction and maintenance of quality security management.

Students cannot expect their personal needs to be met until physiological needs and security needs are met. The need for security can be compromised in the home, on the way to school, in the schoolyard, in the school hallways and restrooms, and in the classroom.

Parents and teachers have a duty to help ensure that security is met as a basic need. Most often, the satisfaction of this need is jeopardized by other students in the school, but it is also jeopardized by students, minors, and adults who do not belong to the school the student (child) attends.

Unfortunately, with untimely and inappropriate actions, the safety of students is compromised by their parents and sometimes teachers. Fear of school is an important indicator of the inadequate satisfaction of the student's need for safety. A student who is stressed or in fear, regardless of the cause, cannot participate normally in class. Furthermore, in a classroom where some students feel insecure, effective learning and quality classes are not possible. Adults (parents and all school staff) are obliged to closely monitor the causes of stress and fear in students, and work to eliminate them so that each student can achieve personal opportunities in the learning process.

The period of transition from childhood to adulthood, known as adolescence, is a period that primarily brings the need to build one's identity and a strong urge to prove oneself and independence. After completing primary school, children must choose and enroll in a high school, which complicates the process of growing up exceptionally. The children are changing their habitual environment, they are learning about new social worlds and gaining a sense of independence.

That transition is a process that requires adaptation to the new school environment, and it brings increased academic demands and changes in peer groups, which can sometimes be a great challenge for individuals (Hargreaves i Earl (1990); Tilleczek i Ferguson, 2007). Each transition, including the one within the school system, brings many unknowns, fears and insecurities, but it also brings an opportunity for a fresh start and change. Authors Osher, Kendziora, Spier, and Garibaldi (2014) state that, even though school should represent a child's safe place, it can sometimes be a place that is associated with negative feelings and behaviors such as violence, 
peer rejection, frustration related to school failure, and even punishment and completely excluding a young person from the school system. The feeling of insecurity and fear can be the result of a real or imagined threat or danger (Meltzer et al., 2007; Zani, Cicognani and Albanesi, 2001). On the other hand, it will depend on real, perceived threats (if, for example, they were directly involved in, or testified to, violence), and if they believe that there is a strong possibility of them becoming victims of violence in that type of situation. For the purposes of this paper, violence is defined as "the use or threat of a physical or psychological force with deliberate intent as a way of resolving conflict" (Arriagada and Godoy, 2000). Whether or not a child is violent is conditioned by a number of factors. Some children are forced by group members to participate in peer abuse (Poredos Lavor et al., 2010).

Different fields analyze the causes of violence across three main levels: structural, institutional and individual (Mcllwaine, 1999). The individual level interprets violence as a rational cost-benefit analysis, where the benefits of the opportunity should be greater than the opportunity cost (Fajnzylber, Lederman, \& Loayza, 2002). Additionally, violence and crime were considered "forms of resistance in economically and socially disadvantaged individuals" (Mcllwaine, 1999). The rapid growth of cities, which has exceeded the capacity of municipalities and the state to provide services and public recreation space, is another factor in the violence. Many authors place risk and protective factors for the development of risky behavior in the child's wider and narrower environment, and in the child himself. Outcomes for the child will depend not only on the risk ratio and the protection it carries within itself, but also on the risks and protections of the environment in which it lives, and on the interaction of all factors (Zloković, Vrcelj, 2010). Scott states (according to Simic, 2004) that aggressive reactions in children are the result of a joint effect of aggressive personality and environmental stimulation. The purpose of this paper will be to analyze differences with respect to environmental stimuli, which implies the spatial determination of the school where the research was conducted. Considering that the research was conducted in five secondary schools, we will analyze and compare certain differences in the act and experience of violence.

The subject of security research in educational institutions is a measure of the sources of vulnerability in and around secondary schools in Sarajevo Canton, and a development and implementation mechanism to minimize peer violence. Safety and violence among students is not a new phenomenon, but there is not enough research in safety and pedagogical literature on this issue. It is partially studied within the framework of teacher studies and professional training of educators. Because of this, teachers are poorly prepared to deal with the problems of safety and violence at school. The consequence is that violence against children, and this includes peer violence, most often remains hidden, even though it is a growing problem.

Our intention was to identify and investigate the problems and specific characteristics of peer violence in secondary schools in Sarajevo Canton, which is a consequence of the current state of society, and the lack of adequate programs and measures for its suppression and prevention in school curricula. The aim of the research was to examine the presence of peer violence, its occurrence, the incidence of peer violence in primary schools, the extent of violence 
occurring in schools, and the adequacy of school and community protection responses, as well as students' awareness of security threats posed by their surroundings.

We believe that the results and analysis of the research conducted may be of benefit to practitioners, theorists and security researchers in educational institutions, as well as to managers and responsible persons when it comes to school safety. We believe that this study may be of particular use to parents, and especially to policy makers in the context of educational institutions in the Sarajevo Canton. We are convinced that the results of the research presented can contribute to raising general awareness, primarily of students and their parents, teachers and school administrations, but also of the general public, about the importance of security threats in and around schools in Sarajevo Canton, as well as accepting responsibility and taking joint efforts to improve security in educational institutions.

Below we will present in detail the way we work: a sample of respondents, research methods and techniques, measuring instruments, organization and flow of research, as well as the results of the research regarding students' attitudes about the feeling of (un)safety in school and the prevalence of forms of the sources of school vulnerability and violence.

A team of researchers from the Faculty of Criminology, Criminology and Security Studies, University of Sarajevo, from October 2018 to December 2018, has created, prepared and successfully implemented this research project. The idea of guiding the creation and implementation of the project "Youth Security in the Sarajevo Canton" starts from the assumption that research is needed that will improve the actions undertaken in the field of prevention of all forms of security threats in educational institutions. Often, young people are resigned precisely because there is no systematically organized approach to prevent phenomena that impair or threaten their safety. The realization of this project shows the contribution of the research team of the Faculty of Criminology, Criminology and Security Studies of the University of Sarajevo in creating an environment in which every student will feel safe, with a unique platform that can serve all formal and informal actors dealing with security problems in educational institutions.

\section{RESEARCH DESIGN AND METHODOLOGY \\ 1.1. Aim and subject of research}

The main objective of this research is to determine the attitudes and opinions of first, second, third and fourth grade high school students in the Sarajevo Canton on safety in school and on the way from home to school. We are aware of the challenges with transitioning that young people face after graduating from elementary school, but also of the important decision-making processes after graduating from high school, so we would like to emphasize the need for an exploratory analysis of youth security issues in this crucial time. 


\section{Seccurity}

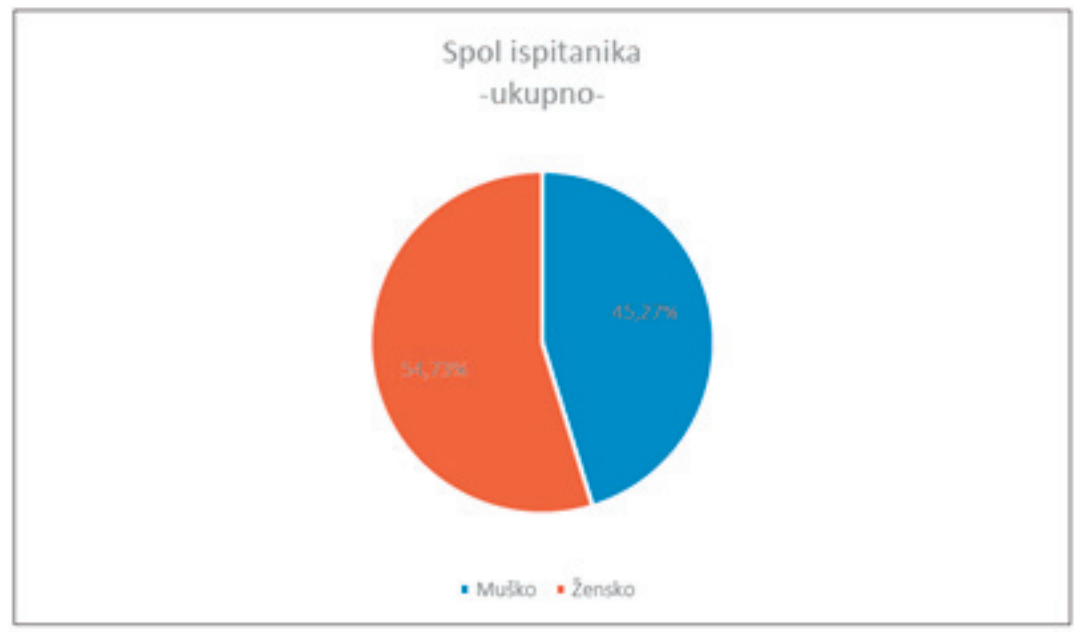

\subsection{Research Methods}

Based on the defined research objective, the design of the research methodology was determined. Research methodology, such as strategy, deals with the researcher's ultimate goal and the general plan that the researcher formulates to achieve his goals (Fitzgerald, 2001). Scientific research, in terms of its type, has been conducted and realized as a methodological research of empirical character. The following methods were used in the research: from the order of the most general research methods and methods of proving and refuting; basic analytical - synthetic methods were used from the group of basic ones; from the general scientific group, the hypothetical - deductive method, the statistical method, but also the axiomatic and comparative method were used; From the data collection complex, the document content analysis method and the test method were used. Since the research in this paper is within the quantitative research paradigm, the quantitative survey method was used as the basic method of data collection. A Survey is a special method of collecting data that can be used to obtain data on the views and opinions of respondents (Vujević, 2002).

\subsection{Research sample and instrumentation}

There are 35 high schools in the Canton of Sarajevo, categorized into four groups: 1. Gymnasiums; 2. technical and related schools; 3. vocational / vocational schools; 4. Art schools (Federal Bureau of Statistics, 2018).

From October 2018 to December 2018, 402 students who participated in research activities were surveyed. The population the study is targeting is first, second, third and fourth grade high school students. The age structure of the respondents during the survey is as follows: out of a total of 402 respondents, 4 students are 14 years old, 64 students are 15 years old, 121 students are 16 years old, 97 students are 17 years old, 103 students are 18 years old and 13 students are 19 years old. With regard to the gender structure of the sample, a total of 182 students and 220 
female students participated in the study, which is an indication of the almost even distribution of the sample by gender. This is illustrated in Chart 1. below.

Chart 1.

The research area covered four municipalities in the Sarajevo Canton as follows: Center, Novo Sarajevo, Novi Grad and Ilidža. The research was conducted in the following secondary schools: Obala High School (Center), Secondary High School for Environment and Wood Design (Novo Sarajevo), Fifth High School (Novi Grad), Fourth High School (Ilidža) and Secondary Technical School of Graphic Technology, Design and Multimedia (llidža). The data collection phase was implemented between October 2018 and December 2018, which means it was in the timeframe of the 2018/2019 school year. It is important to point out that the departments were selected to insure that care was taken to survey the classes that were present at the pre-determined moment of the survey. In this way, the research team, in collaboration with the school's professional associates, sought to ensure "sample randomness" and a more relevant mapping of the characteristics of the selected population.

Specifically, the aim of the research was to examine students' attitudes about school safety. For the purposes of the research, a student questionnaire was constructed to represent a combination of closed and open ended questions. The questionnaire consists of a total of nine content units:

1. questions about you;

2. questions about your family;

3. questions about your school;

4. some unpleasant situations that may have occurred to you;

5. questions about your free time and your peers;

6. an opinion on the aforementioned claims;

7. questions about things young people sometimes do;

8. what others would think;

9. questions about your friends.

Research using anonymous questionnaires is considered to be the most reliable method for assessing students' attitudes to the issue of safety, as it allows children to speak directly about their own experiences (Sesar, 2011). On the other hand, another advantage of this method is that it gathers a large amount of information over a short period of time, which helps find out a great deal about the phenomenon under study. The Student Questionnaire consists of 50 questions divided into nine substantively separate blocks that ask questions about feelings of child safety, peer violence, the presence of violence in school, forms of violence, and general forms of vulnerability in school. The questionnaire is a combination of closed (41) and open (9) questions.

Five secondary schools are included in stratified sampling according to the criterion of socio-ecological environment (urban and suburban):

1. Obala High School (urban area)

2. High School for Environment and Wood Design (Urban) 


\section{Security}

3. Fifth High School (Urban Area)

4. Fourth High School (Suburban Middle)

5. High School of Graphic Technology, Design and Multimedia (suburban environment)

\subsection{Organization and flow of research}

Any research involving children and minors requires adherence to certain ethical principles in its conduct by the researcher. The specificity of the problem addressed necessitated the observance of the minimum standards prescribed by the Code of Ethics for Research with Children and Children in Bosnia and Herzegovina, a document based on ethical principles of respect for human rights, freedoms and dignity of persons, protection of the well-being of research participants, responsibility in moral dilemmas, and protecting the integrity of research results and researchers. Compliance with these principles ensures that research is conducted in a systematically and methodologically acceptable manner, ethically justified and in the best interests of the child as a research participant.

In accordance with the provisions of the said Code, the consent of the Ministry of Education, Science, Culture and Sports of the Sarajevo Canton was first requested to conduct research in selected schools. After the approval was obtained, the same was presented to the principals of the said schools. The students completed the questionnaires during one class session with the presence of a class leader. In order to ensure the honesty of the answers, the survey was anonymous.

The data collected through the survey were entered into a single database using the Google platform, after which the analysis was performed using descriptive and inferential statistics.

\subsection{Limitations and challenges of the research}

When it comes to methodological limitations, it can be assumed that the respondents did not give the most sincere answers when filling in the questionnaires for reasons such as fear, shame, desire to prove, power, attention, etc., and because of the possible feeling of insufficient anonymity, since the questionnaire is filled in in a group during one lesson.

It is also possible that using a frequency scale with fewer sections, such as three sections instead of five, would make it easier to complete the questionnaire for individual questions and provide more reliable results. For example, Karlovic (2001) considers that scales with fewer compartments are more reliable than those with more compartments.

\section{RESULTS AND DISCUSSION}

Within each listed school, one class per year/generation is included. In the Municipality Center, at the school "Gymnasium Obala", 68 students participated in the survey. In the Municipality Novo Sarajevo at the "Secondary school for environment and wood design", 90 students were surveyed. In the Municipality Novi Grad, at the school "Fifth Gymnasium" 94 students participated in the survey, while 75 students were surveyed in the llidža Municipality at the Fourth 


\section{Secuurity}

High School, and 75 students at the "Secondary Technical School of Graphic Technology, Design and Multimedia".

Chart 2. shows the structure of the overall sample, which consisted of four classes per year, selected by the random selection method, in accordance with the element of student availability in the period of arrival of the interviewer. Furthermore, in terms of sample structure, a total of 90 first-grade students, 92 second-grade students, 104 third-grade students and 116 fourthgrade high school students in the Sarajevo Canton participated in the survey.

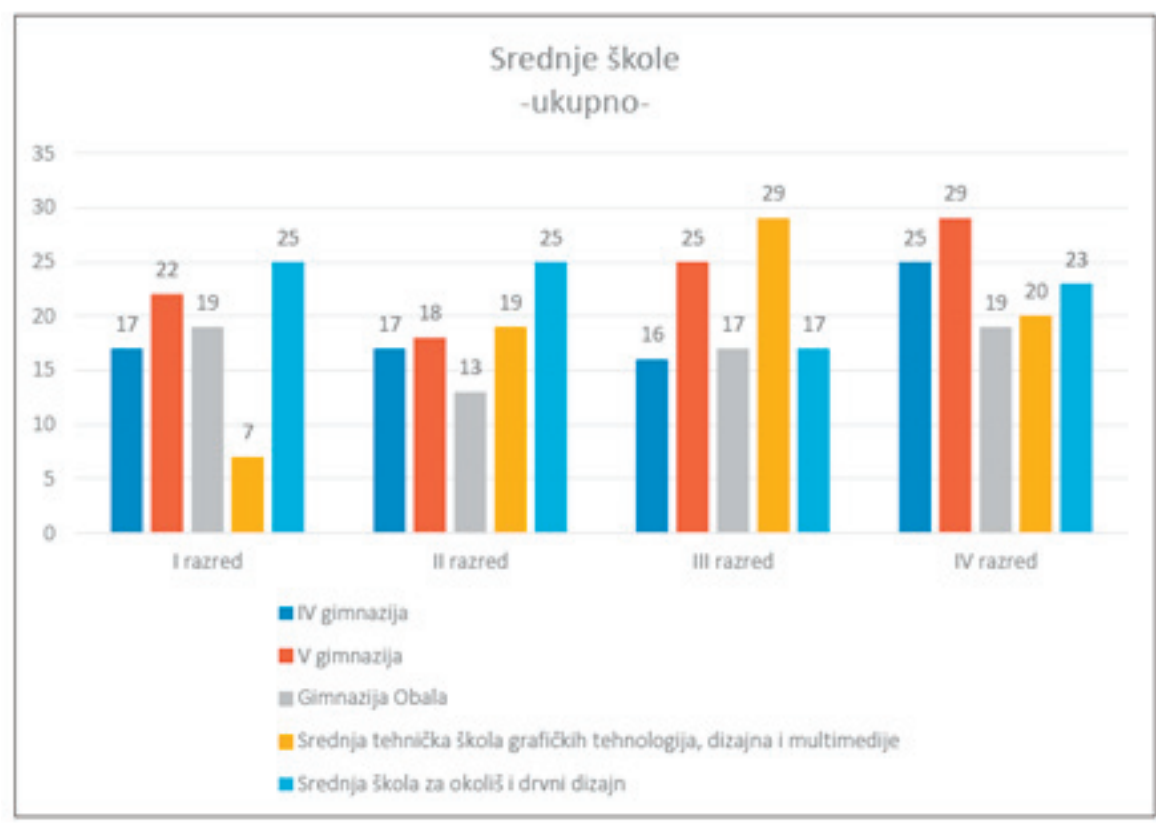

Chart 2.

\subsection{Students' awareness of the feeling of safety in school and the prevalence of forms of sources of vulnerability and violence for first-year high school students}

When it comes to the results of the survey for the first grade respondents, it is important to note that a total of 90 students participated in the survey. Out of the total number, 52 male students and 38 female students took part. The age structure of the respondents is as follows: 64 respondents are 15 years old, 22 respondents are 16 years old and 4 respondents are 14 years old. In the block of questions about the educational aspect, summarized data show that in $90 \%$ (81 respondents) of cases, both parents participate in the upbringing of students. It is evident that the socio-economic situation is reflected in a relatively large percentage of employed parents (fathers $89 \%$ - 79 and mothers $61 \%$ - 53). When asked "How does your family make income (money)", 96.6\% of the respondents (86 students) answered that salaries, earnings or assets are their typical source of income. First-graders, when asked about the comparison of financial 
opportunities with other families, in $53.4 \%$ of cases answered that they were in the same financial situation as in others, while in $42 \%$ of cases, respondents considered that they were in a better financial situation than in others. The fact that $72 \%$ of students dine with their parents daily is confirmation of strong family ties and cohesiveness between young people and parents/ guardians. It is interesting to note that $93.2 \%$ of young people estimate that they have a good or above average grade point average. A very low percentage of absenteeism is evident; $22 \%$ of first-year high school students' answers to the question of being absent from school for at least one full day in the last 12 months. Only two respondents from the entire sample were repeating the year for the first grade of high school. Graph 3. refers to projections of the future of young people. It is important to point out that $61.8 \%$ of young people are already thinking about college after graduating from high school, $4.5 \%$ of young people are thinking about continuing their education through other forms of learning, $15.7 \%$ young people are considering employment, while the rest of the respondents still do not have a definite picture of the future.

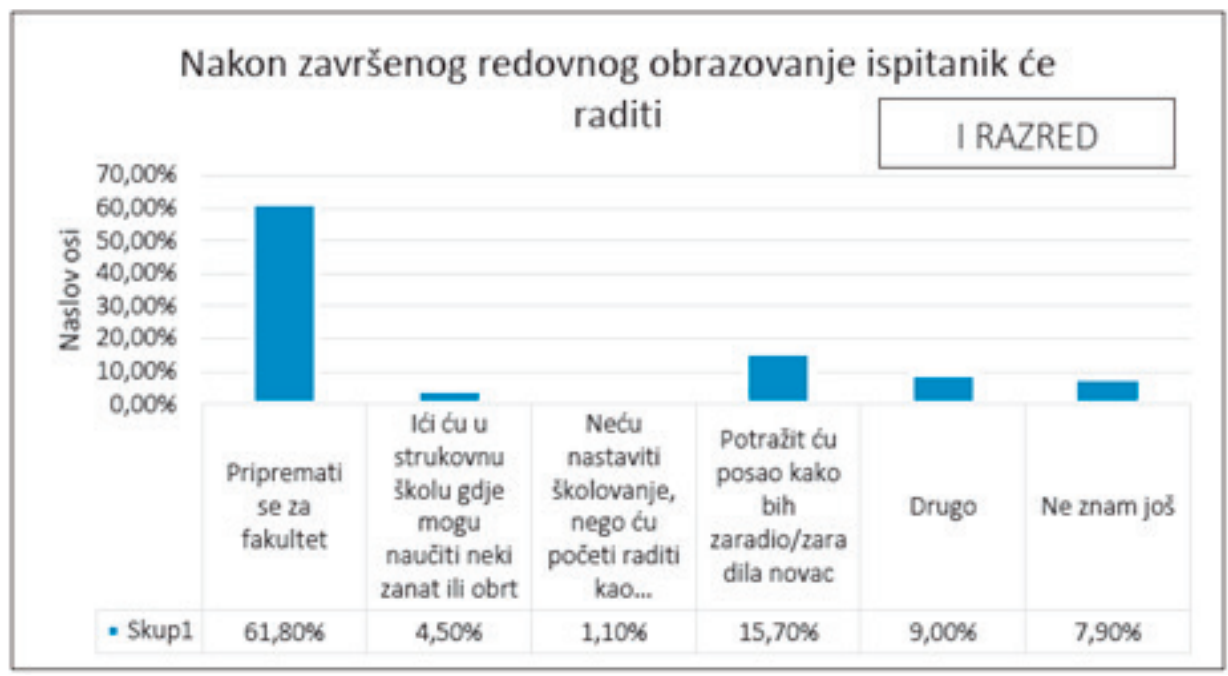

Graph 3.

Students' perceptions of potential sources of vulnerability arising from (inadequate) conditions for the upbringing and education process in and around the school (both the teaching process and school and yard infrastructure) were also explored.

Charts 4. and 5. are the focus of research attention, as it is noticeable that students were more explicit in answering questions about parts of school infrastructure and physical violence, which confirms that the sources of vulnerability to infrastructure and peer violence are represented to some extent in these schools. When it comes to claims regarding the infrastructure, conditions and equipment of the school, it can be concluded that $21 \%$ of students have a negative attitude towards the state of affairs in the school they attend. Infrastructure and (in)equipment of the school is a category separately themed in the "Strategic Directions of Education 


\section{Seccurity}

in Bosnia and Herzegovina with Implementation Plan" (2008), which highlights the problem of maintaining school facilities, because there are insufficient capital allocations for educational institutions. Lack of school space also has a negative impact on the quality of the teaching process.

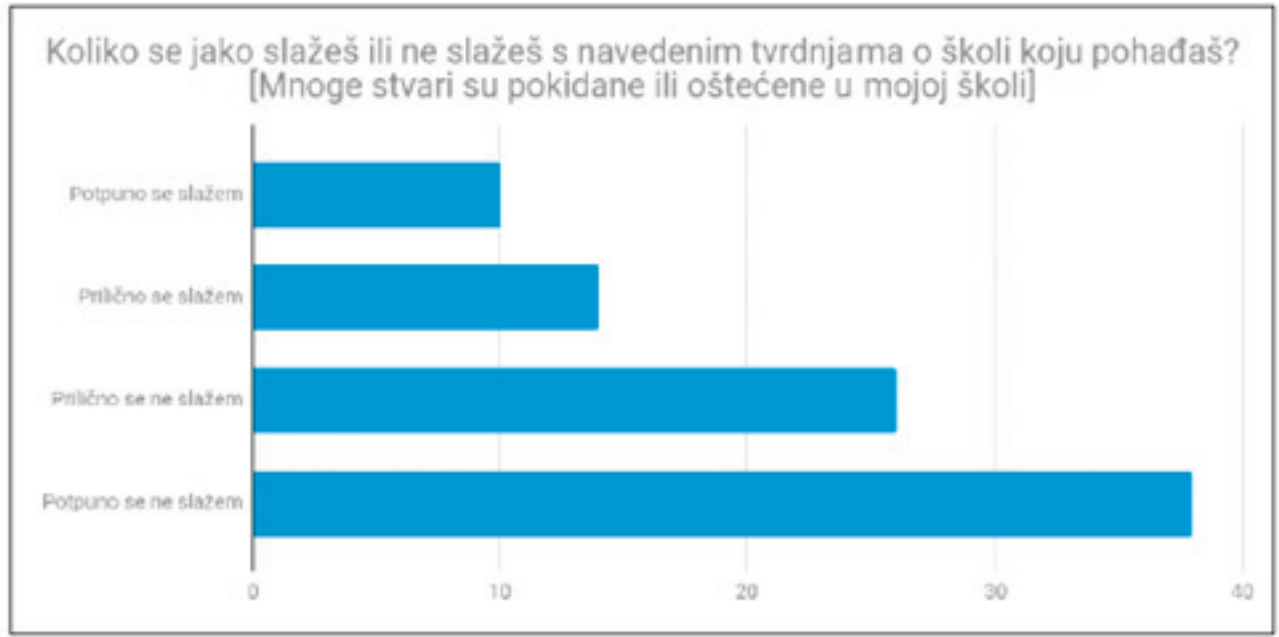

Chart 4.

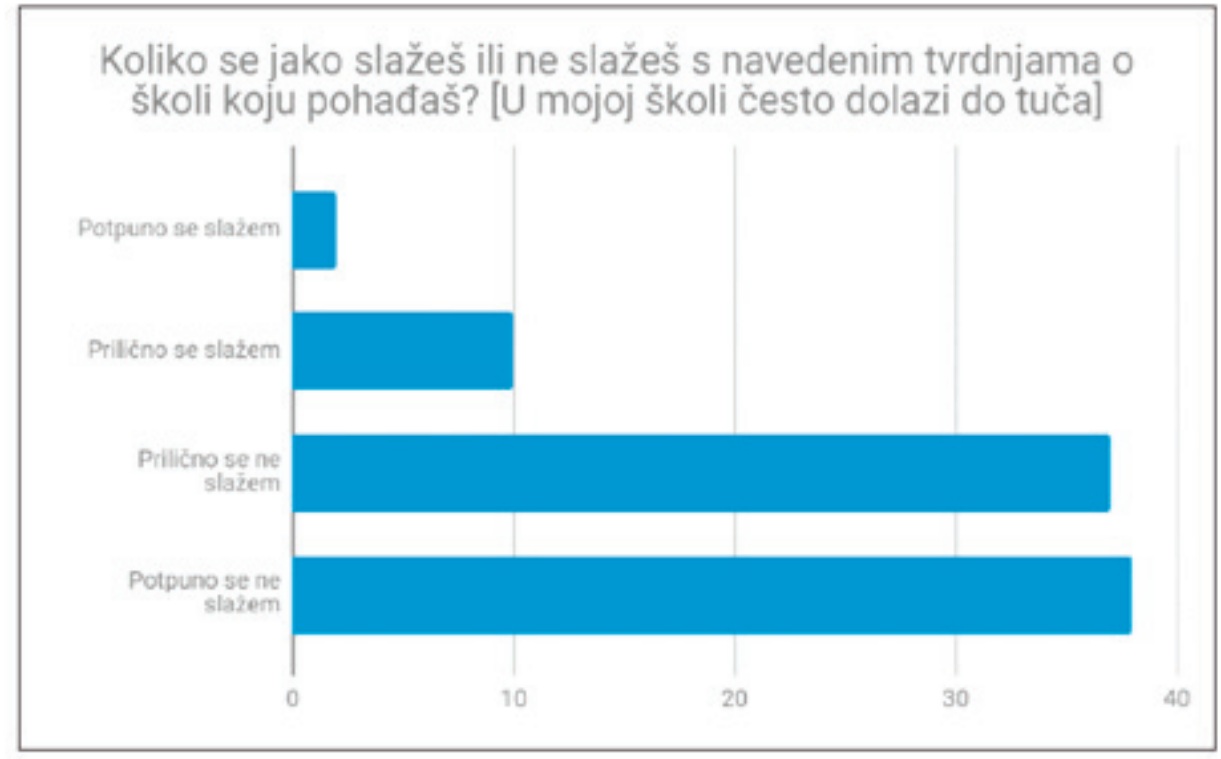

Chart 5. 


\section{Security}

The various security crises that occur in numerous educational institutions present a challenge for society and individuals, as well as for the school and the education system as a whole. In many types of security threats in the school environment, the tragic consequences and reverberations in the public highlight different forms of violence in school settings, which imply grave consequences for the community and the school. Due to their apparent visibility and striking dramatic nature, such cases were put at the forefront of the analysis, in order to look at current possible approaches, predictions, and prevention of such crises. The results of the research show that in this case $10 \%$ of students replied that there was often a brawl at their school, which is evident in chart 6 . below.

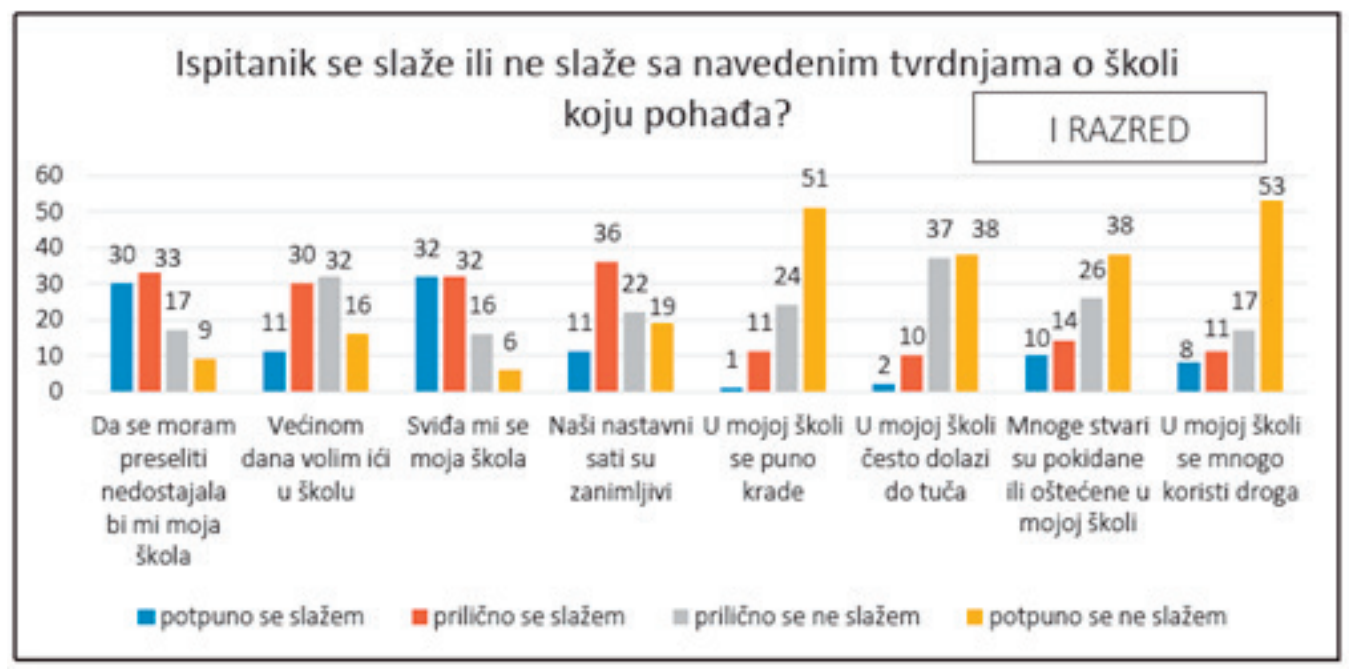

\section{Chart 6.}

The findings of other research studies suggest that, even though they are aware of what is happening in a peer environment, observers of violence generally do not respond or take action for three main reasons: they do not know what to do, they fear that they will become a victim of bullying themselves, or they are they will make the situation worse (Cowie, 2004). In circumstances of limited insight into their own emotional responses to peer violence and poorly developed skills of adequate response, observers, although possessing the potential to play a supportive role in solving interpersonal problems at the peer group level, opt for non-intervention as the safest option. In this way, not only is their potential contribution and support for the victim of violence lost, but the observers themselves have consequently lowered self-esteem, because of the knowledge that they were not helpful to the person in need. They often develop feelings of powerlessness similar to the one that the victim experiences (Hazler, 1996).

Within the question of things that young people sometimes do, it is interesting that, at the level of the whole sample, a large number of young people (84.3\%) state that they do not carry any weapons (sticks, knife, gun or chain), while on the other hand, $15.7 \%$ of respondents stated 
that they carry one of the listed weapons (a stick, a knife, a gun or a chain), which can serve as a means of self-defense. However, the question arises as to whether such resources are indeed used for self-defense and whether there is a justifiable need to bring such things to schools, schools that should provide their students with a certain level of protection against all threats.

The next question refers to personal involvement in the fight as a physical form of violence. At the overall sample level, $82 \%$ of respondents stated that they had never been in a fight. In fights at sports stadiums, streets or other public places, $18 \%$ of respondents, according to the survey, actively took part in such situations. Since the questioning was anonymous, but in direct contact with the interviewer, it is possible that these figures are higher. When asked "Did someone violently hit you or hurt you so badly that you had to go to the doctor?" Four students answered in the affirmative. The same number answered in the affirmative to a question related to giving money/other valuable items when being threatened.

When it comes to physical punishment by parents as a measure of sanction, the results show that $28.10 \%$ of respondents were in the situation of being hit, slapped, or pushed by their mother or father, while $12.40 \%$ of respondents were exposed to more severe punishment ( "Hit with an object, leg, fist"). Numerous frustrations of parents are caused by economic problems, and often long-lasting consequences of war. These frustrations are passed on to children, which leads to a weakening of parental contact with the child, thus breaking the key link in determining the value of a young person's world. Then problems at school become more apparent, so the young person finds similar people and spends more time with them, and starts to share similar values. It is of the utmost importance to provide insight into the unacceptability of a child's violent behavior, because their view is a product of violence and aggression that is constantly encouraged or tolerated by social circumstances and the media.

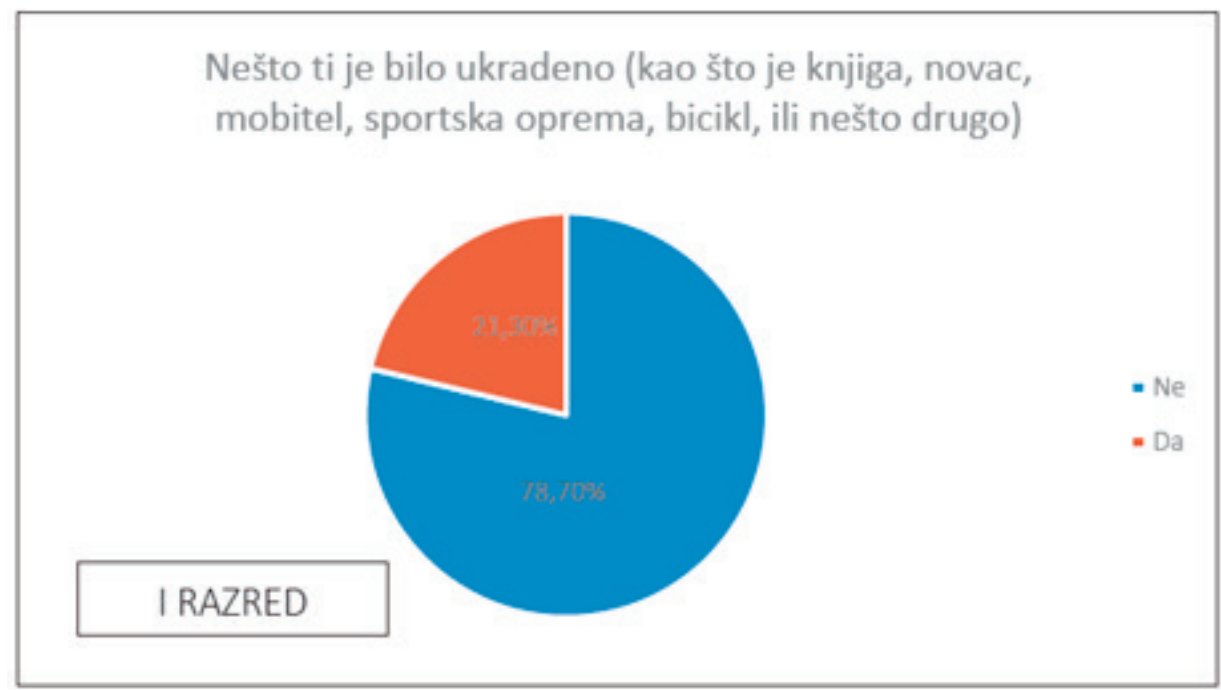

Chart 7. 


\section{Security}

In the block of questions concerning deviant and illicit behavior, there are noticeable behaviors that are punishable under BiH misdemeanor and criminal laws.

According to Chart 7, it is evident that almost every fifth student says that something of theirs has been stolen (book, money, cellphone, sports equipment, bicycle, or something else).

Furthermore, the results of the survey show that $10 \%$ of students answered that stealing is frequent at their school. $28.8 \%$ of students said they had a friend who stole something from the store. $44.8 \%$ of female students stated that they had a friend who took light and heavy drugs, such as marijuana, hashish, ecstasy, speed, heroin or cocaine.

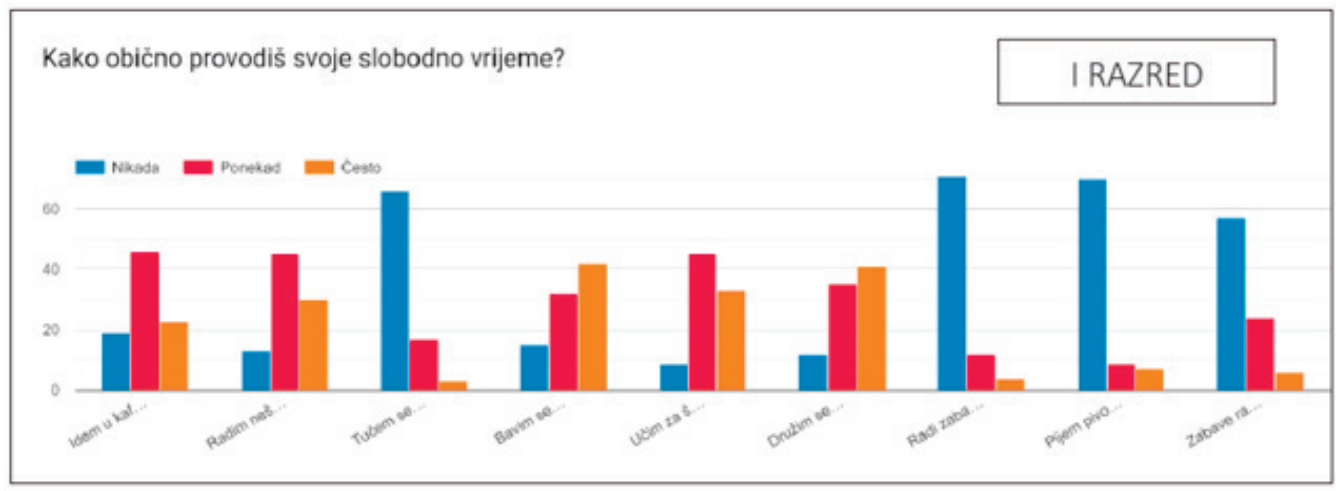

$21.10 \%$ of the students surveyed answered that they never go out in the evening, for example to a party, to hang out at someone else's house, or to hang out in the neighborhood, while on the other hand, $5.6 \%$ of the first grade students responded that they go out to dinner every day, and $73.2 \%$ of them at least once a week. The teenage years (growing up and maturing) bring many challenges and temptations to young people. Education and classes are the main or basic activities to be undertaken on the path to obtaining a status of maturity, but various other contents and activities are on their priority list (Pastuović, 1997; Vasta, et al. 1998; Vizek Vidović et al., 2003). Free activities (hobbies) are defined as activities that individuals engage in when they do not work or go to school. These activities are voluntary, intrinsically motivated, and require more initiative, organization and regulation than activities determined by others (Larson and Verma, 1999). The results of the survey on spending free time are shown in Graph 9. The time that young people strive to fill with activities that are substantially different from those provided in the teaching process and in school spaces is to some extent an act of courage or even progressive behavior. For example, almost every sixth student confirms that they sometimes or often take part in fights with others (17\%), while $14 \%$ of respondents confirm that they sometimes or often "do something illegal" for fun. The percentage of students (26\%) who "have fun scaring people and annoy them" is slightly higher. $35 \%$ of respondents say they will sometimes take the risk just for fun.

In the block of questions related to socializing with friends and forming a group, it is obvious that the teenage years dictate the beginning of socialization. It is evident that in $90.9 \%$ of 
the first grade students confirmed that they had a friend or a group of friends with whom they spend their free time, with whom they socialize and have fun. On the scale of responses in the "plenty" and "very much" intervals, a total of $91.9 \%$ of students answered that they would miss their friends if they had to move to another city. When it comes to the age of friends for the first-year high school students, $84.7 \%$ of the population is aged $15-18$. It is important to note that $71.8 \%$ of respondents say that they spend time with friends in places such as parks, streets, shopping malls or neighborhoods. However, for $16.7 \%$ of young people doing illegal things is acceptable to their group of friends, while $11 \%$ of the respondents said that people in the group do illegal things together. $9.5 \%$ of those surveyed see their group of friends as a gang. There is a very small percentage $(6.7 \%)$ of first grade students who have had contact with the police because they have done something illegal. Consumption of light drugs is at a very low level (cannabis - $6.8 \%$ and ecstasy - $3.4 \%$ ), while consumption of alcoholic beverages is at a much higher level (38.6\%).

According to data from Love Our Children USA (2012) in the United States, in a sample of 6 million children, one in seven children make contact with online predators every day, one in four experience bullying. $43 \%$ of US students report that they survived online harassment. The situation in Bosnia and Herzegovina on this issue is not clear enough. The reasons for this situation are many, however, the lack of awareness of risk and the lack of adequate measures for the protection of children on the Internet are the basic starting points for further elaboration of the mentioned problems (Ahić, Hadžikadunić, Budimlić, Halilović-Kibrić, Hodžić, Cucak, 2019). Respondents in the first grades of secondary schools in $11.2 \%$ of cases stated that they were mocked or severely teased in a harmful way on the social networks they use.

\subsection{Students' awareness of the feeling of safety in school and the prevalence of forms of sources of vulnerability and violence for second-year high school students}

When it comes to the results of the survey for the second grade students, it is important to note that a total of 92 students participated in the survey. Out of the total number, 36 male students and 56 female students took part. The age structure of the respondents is such that 91 respondents are 16 years old and 1 respondent is 17 . In the block of questions about the upbringing aspect, the summarized data shows that in $87.8 \%$ (79 respondents) of cases, both parents participate in the upbringing of students. It is apparent that the socioeconomic situation shows a relatively large percentage of employed parents (fathers $74.7 \%$ - 68 and mothers $56.7 \%$ - 51). When asked "Where does your family income come from (money)", $92.3 \%$ of the respondents (84 students) answered that salary, earnings or property is a typical source of income. Second-grade students, when asked about the comparison of their financial situation with other families, in $65.2 \%$ of cases answered that they are in a similar financial situation as others, while $71.7 \%$ of respondents considered to be in a better financial situation than others. The fact that $65.9 \%$ of students dine with their parents daily confirms strong family ties and cohesiveness between young people and parents/guardians. It is interesting that $40.2 \%$ of young people estimate that they have an above average grade point average. 


\section{Security}

There is a relatively small percentage of students who have been absent for at least one full day in the last 12 months, which is noticeable in $32.9 \%$ of answers in second-grade students. Only one respondent from the entire sample for the second grade of high school is repeating the second year. In the section concerning projections of the future of young people, it is important to point out that $79.1 \%$ of young people are already thinking about college after graduating from high school, while only $3.3 \%$ of young people are considering immediate employment.

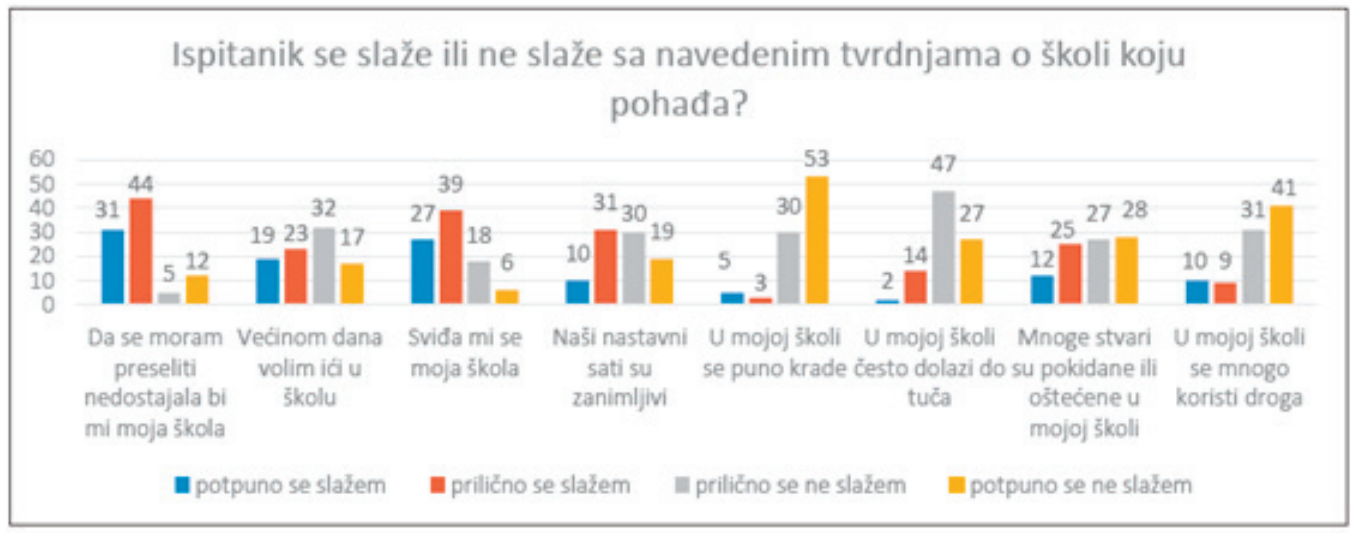

When it comes to claims regarding the school's infrastructure, condition, and equipment, it can be concluded that $40 \%$ of the students agreed with the statement that many things in their school were damaged or are damaged, as can be seen in Chart 10. In the section dealing with youth behavior, it is important to highlight the answers to questions regarding writing/ spray painting the building and the entrance to the building, trams and so on, which is present in $34.7 \%$ of students. On the other hand, almost $46.7 \%$ of the surveyed fourth-grade high school students downloaded illegal content online. Within the question of things that young people sometimes do, it is interesting that, at the level of the whole sample, the largest number of young people (94.5\%) state that they do not carry any weapons (sticks, knife, gun or chain), while 5,5\% of respondents stated that they carry one of the following types of weapons (a stick, a knife, a gun or a chain) which can serve as a means of self-defense.

The next question concerned personal involvement in a fight as a physical form of violence. At the overall sample level, $90.2 \%$ of respondents stated that they had never participated in a fight. In fights at sports stadiums, streets or other public places, according to the survey, $9.8 \%$ of respondents actively participated in such situations. Civen that the questioning was anonymous, but in direct contact with the interviewer, it is possible that these figures are higher. When asked "Has anyone hit you or hurt you so badly that you had to see a doctor?" three students answered yes. One student answered in the affirmative when asked about having to give money or other valuable items when threatened.

Regarding physical punishment by parents as a measure of sanction, Charts 11 . and 12 . show that $30.8 \%$ of respondents were in the situation of being hit, slapped or pushed by their mother 


\section{Securiaty}

or father, while $11 \%$ of respondents were exposed to severe a form of punishment ("hit with an object, leg, fist or beaten").
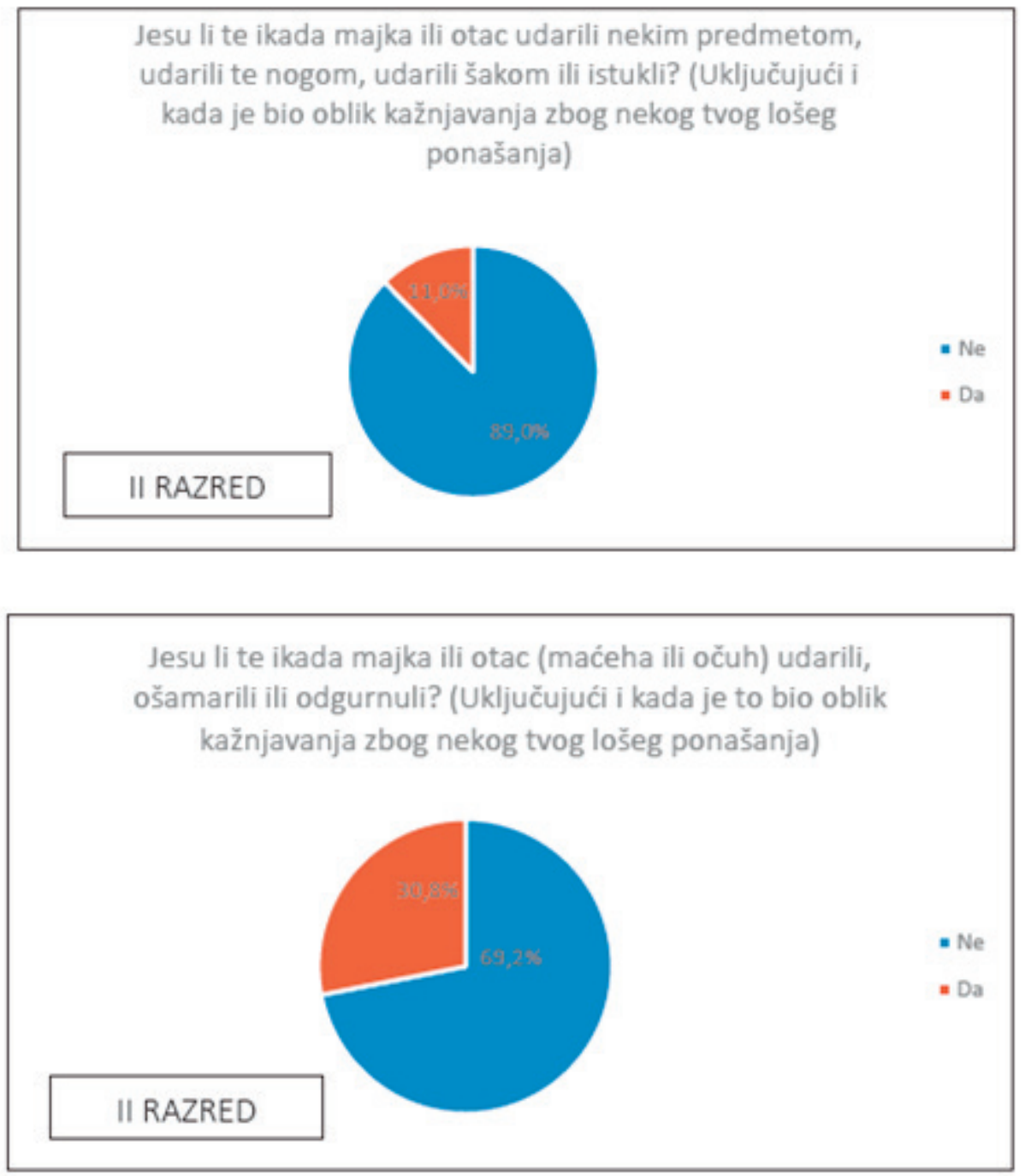

In the block of questions concerning deviant and illicit behavior, there are noticeable behaviors that are punishable under $\mathrm{BiH}$ misdemeanor and criminal laws. It is evident that $15.4 \%$ of students say that something of theirs has been stolen (book, money, cellphone, sports equipment, bicycle, or something else). Furthermore, the results of the survey show that $8.8 \%$ of students answered stealing is frequent at their school. $17.7 \%$ of students stated that they had a friend who stole something from a store, which is shown in graph $13.37 .5 \%$ of students said 


\section{Secuurity}

they had a friend who took light and heavy drugs, such as marijuana, hashish , ecstasy, speed, heroin or cocaine.

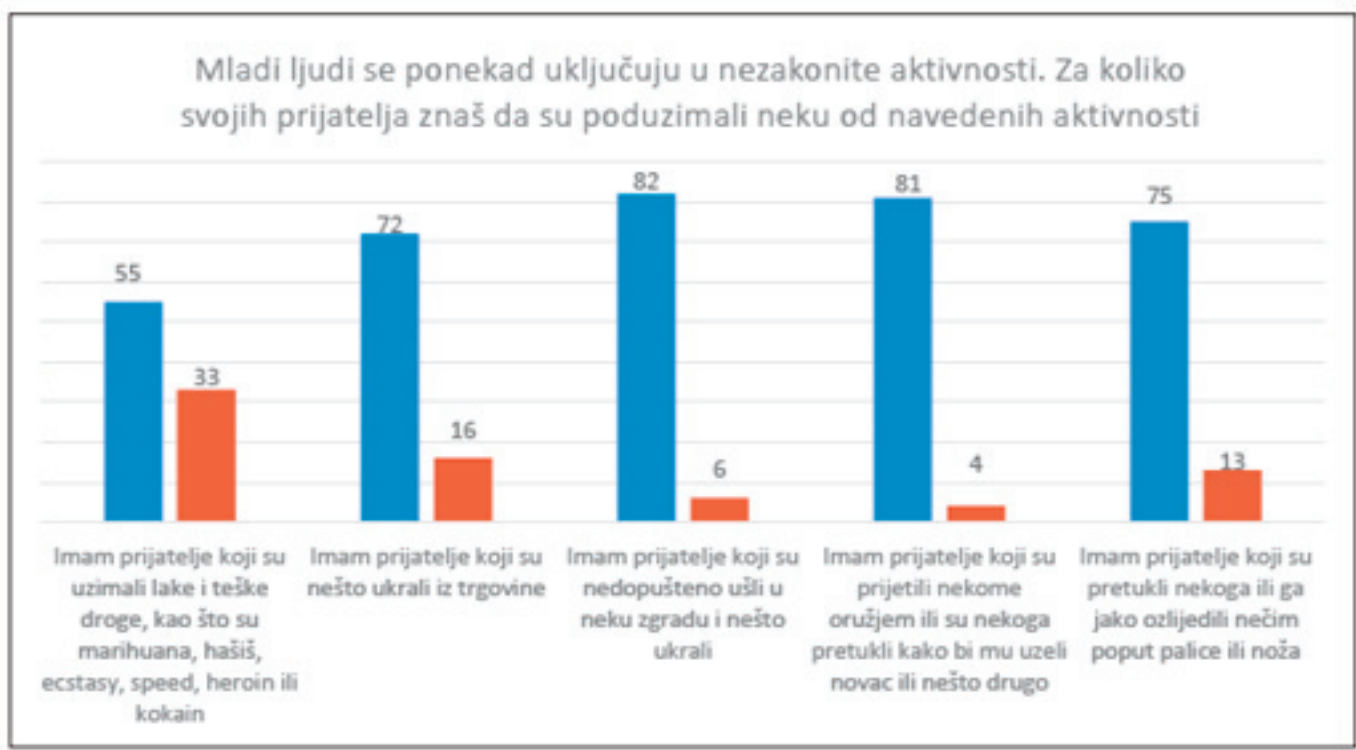

$21.7 \%$ of the students surveyed said that they never go out in the evening, for example to a party, to hang out at someone else's house or hang out in the neighborhood, while $2.2 \%$ of the second-grade students surveyed said they go out for dinner every day, and $76.1 \%$ at least once a week.

The results of the free time survey are shown in Chart $14.11 .9 \%$ of students confirm that they sometimes or often participate in fights with others, while $9.9 \%$ of those surveyed confirm that sometimes or often they "do something illegal for fun." The percentage of students (39.5\%) who "have fun scaring people and annoying them" is slightly higher. Also, 70.65 second-grade students stated that they play sports, fitness or some other form of exercise.

In the block of questions related to socializing with friends and forming a group, it is obvious that the teenage period is the beginning of socialization. $95.6 \%$ of second-grade students confirmed that they had a friend or a group of friends with whom they spend their free time, with whom they socialize and have fun. On the scale of responses in the "plenty" and "very much" intervals, a total of $93.4 \%$ of students answered that they would miss friends if they had to move to another city. 


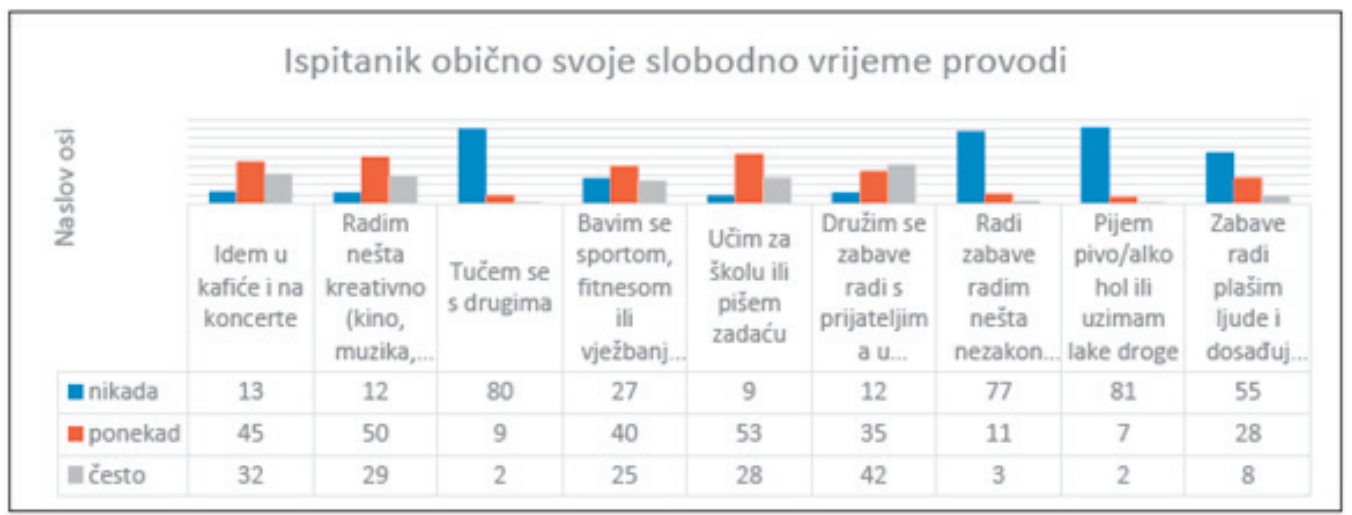

The age of friends for respondents in the second year of high school is $15-18$ in $93.3 \%$ of cases. It is important to note that $82.2 \%$ of respondents say that they spend time with friends in places such as parks, streets, shopping centers or neighborhoods. However, for $11.2 \%$ of young people, doing illegal things is acceptable to their group of friends, while $12.4 \%$ of the respondents said that people in their group do illegal things together. $4.4 \%$ of the students associate their group of friends with a gang.

There is a very small percentage (6.5\%) of second-grade students who have had contact with the police because they have done something illegal. Consumption or "trying" of cannabis is low $(12 \%)$, while consuming or "trying" alcoholic beverages is much higher (46.7\%).

In $13.2 \%$ of cases, the second-grade students stated that they were mocked or severely teased in a harmful way in the social networks they use.

\subsection{Students' awareness of the feeling of safety in school and the prevalence of forms of sources of vulnerability and violence for third-year high school students}

When it comes to the results of the survey for the third-grade students, it is important to note that a total of 104 students participated in the survey. Out of the total number, 36 male students and 68 female students took part. The age structure of the respondents is such that 8 respondents are 16 and 96 respondents are 17 years old. In the block of questions about the upbringing aspect, the summarized data shows that in $86.2 \%$ (88 respondents) of cases, both parents participate in the upbringing of students. It is apparent that the socioeconomic situation shows a relatively large percentage of employed parents (fathers $78.2 \%$ - 79 and mothers $71.3 \%$ - 72). When asked "Where does your family income come from (money)", $97 \%$ of the respondents (84 students) answered that salary, earnings or property is a typical source of income. Third-grade students, when asked about the comparison of their financial situation with other families, in $53.9 \%$ of cases answered that they are in a similar financial situation as others, while $30.2 \%$ of respondents considered to be in a better financial situation than others. The fact that almost two thirds of students dine with their parents daily confirms strong family 


\section{Securitity}

ties and cohesiveness between young people and parents/guardians. It is interesting that $96.7 \%$ of young people estimate that they have a good or an above average grade point average. Only one student in the whole sample is repeating the third grade.

Chart 15. shows the future of the youth. $73.8 \%$ of young people are already thinking about college after graduating from high school, while only $12.6 \%$ of young people are considering immediate employment. The rest do not have a clear vision about their future plans yet.
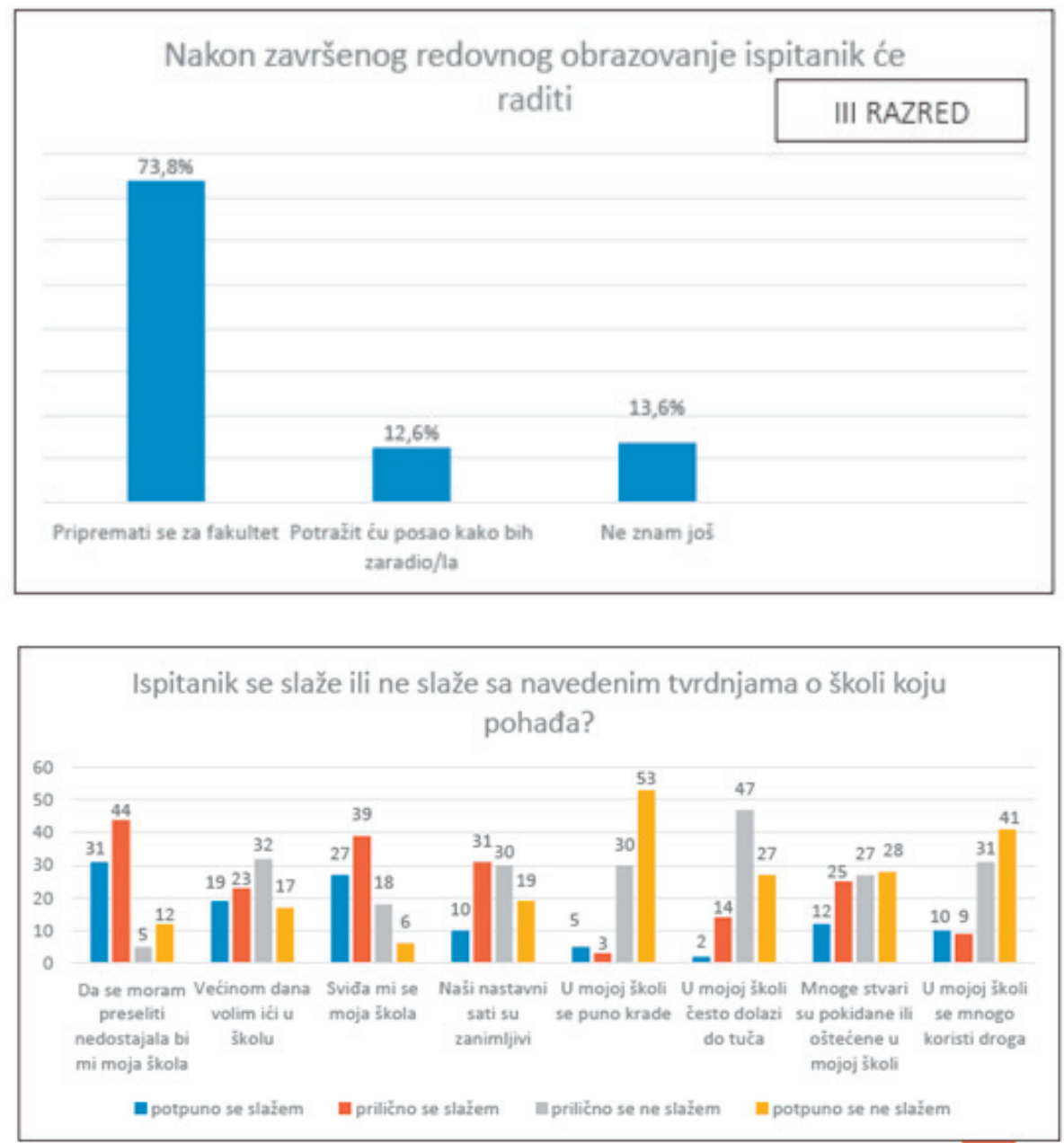

When it comes to claims regarding the school's infrastructure, condition, and equipment, it can be concluded that $57.2 \%$ of the students showed a negative opinion regarding the state of things in the school they go to. On the other hand, $72.9 \%$ of students said they like their school (Chart 16). 
Within the question of things that young people sometimes do, it is interesting that, at the level of the whole sample, the largest number of young people (90.3\%) state that they do not carry any weapons (sticks, knife, gun or chain), while $9.7 \%$ of respondents stated that they carry one of the following types of weapons (a stick, a knife, a gun or a chain) which can serve as a means of self-defense. We must wonder whether these things are really used for self-defense, and if there is another reason for the possession of such items.

The next question concerned personal involvement in a fight as a physical form of violence. At the overall sample level, $88.4 \%$ of respondents stated that they had never participated in a fight. In fights at sports stadiums, streets or other public places, according to the survey, $11.6 \%$ of respondents actively participated in such situations. Civen that the questioning was anonymous, but in direct contact with the interviewer, it is possible that these figures are higher. When asked "Has anyone hit you or hurt you so badly that you had to see a doctor?" three students answered yes. One student answered in the affirmative when asked about having to give money or other valuable items when threatened.

Regarding physical punishment by parents as a measure of sanction, results show that $31 \%$ of respondents were in the situation of being hit, slapped or pushed by their mother or father, while $10 \%$ of respondents were exposed to severe a form of punishment ("hit with an object, leg, fist or beaten").

In the block of questions concerning deviant and illicit behavior, there are noticeable behaviors that are punishable under $\mathrm{BiH}$ misdemeanor and criminal laws. According to chart 17., every fifth student says that something of theirs has been stolen (book, money, cellphone, sports equipment, bicycle, or something else).

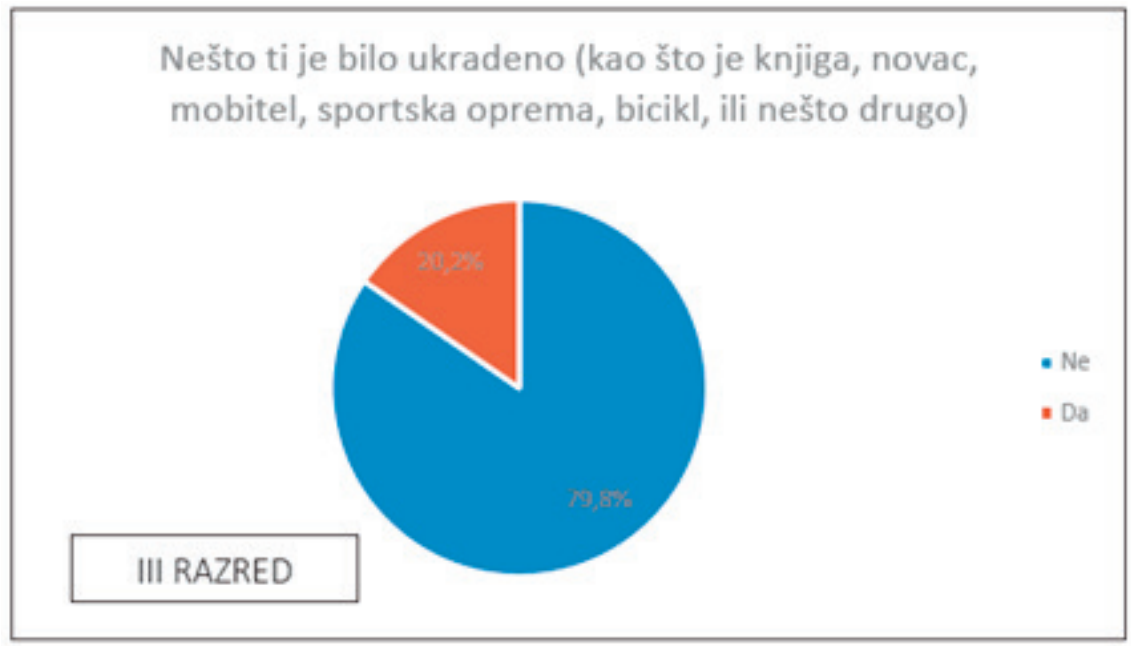

Furthermore, the results of the survey show that $11 \%$ of students answered that stealing is frequent at their school. $21 \%$ of students stated that they had a friend who stole something from 
a store, which is shown in graph $18.42 .7 \%$ of students said they had a friend who took light and heavy drugs, such as marijuana, hashish, ecstasy, speed, heroin or cocaine.

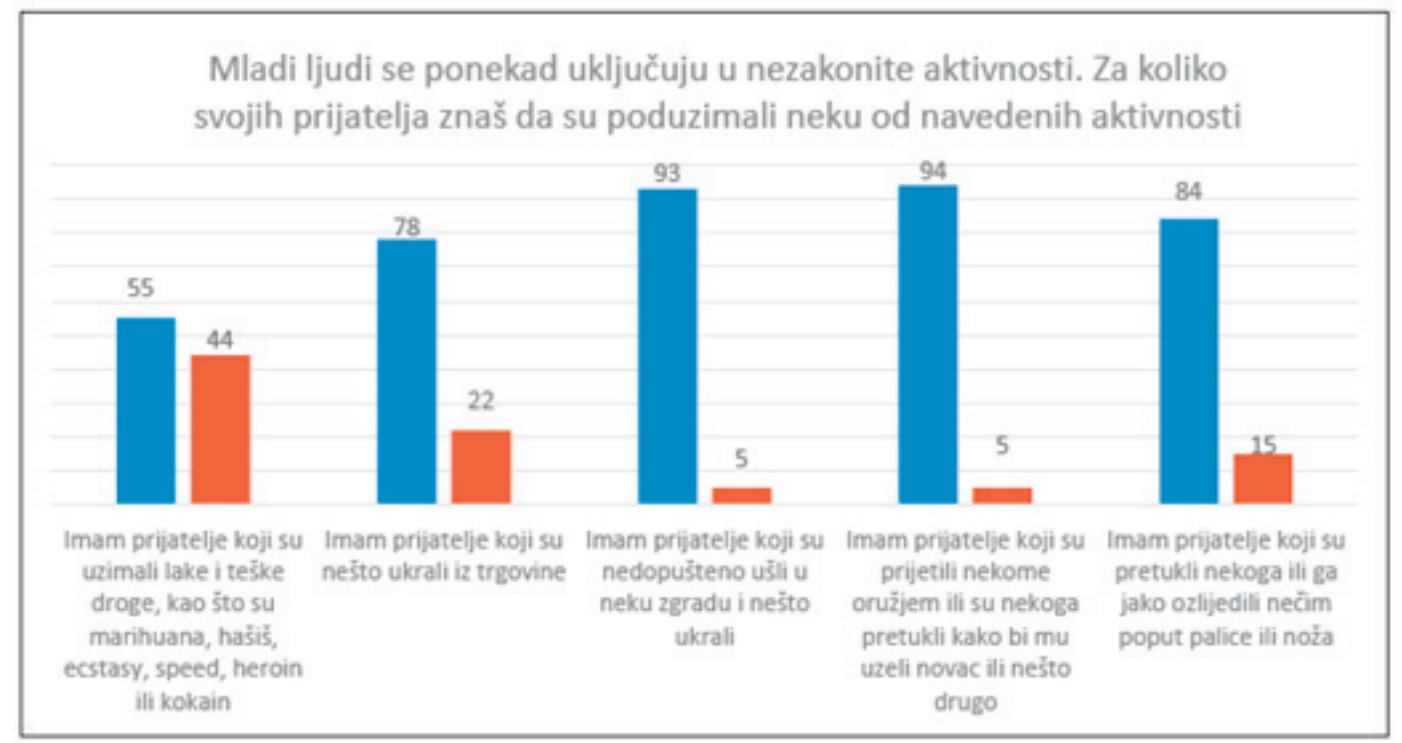

$15.4 \%$ of the students surveyed said that they never go out in the evening, for example to a party, to hang out at someone else's house or hang out in the neighborhood, while $8.7 \%$ of the third-grade students surveyed said they go out for dinner every day, and $75.9 \%$ go out at least once a week.

The time that young people strive to fill with activities that are substantially different from the ones provided to them in school spaces is to some extent an act of courage or even progressive behavior.

However, $17 \%$ of students confirm that they sometimes or often participate in fights with others, while $29.1 \%$ of those surveyed confirm that sometimes or often they "do something illegal for fun." $94.1 \%$ of participants say they go to cafes and concerts. $39.5 \%$ of third-grade students "have fun scaring people and annoying them".

In the block of questions related to socializing with friends and forming a group, it is obvious that the teenage period is the beginning of socialization. $90.9 \%$ of third-grade students confirmed that they had a friend or a group of friends with whom they spend their free time, with whom they socialize and have fun. On the scale of responses in the "plenty" and "very much" intervals, a total of $72.3 \%$ of students answered that they would miss friends if they had to move to another city.

It is important to note that $72.3 \%$ of respondents say that they spend time with friends in places such as parks, streets, shopping centers or neighborhoods. However, for $24.2 \%$ of young people, doing illegal things is acceptable to their group of friends, while $15.1 \%$ of the respon- 
dents said that people in their group do illegal things together (Chart 19.). $8.5 \%$ of the students associate their group of friends with a gang.

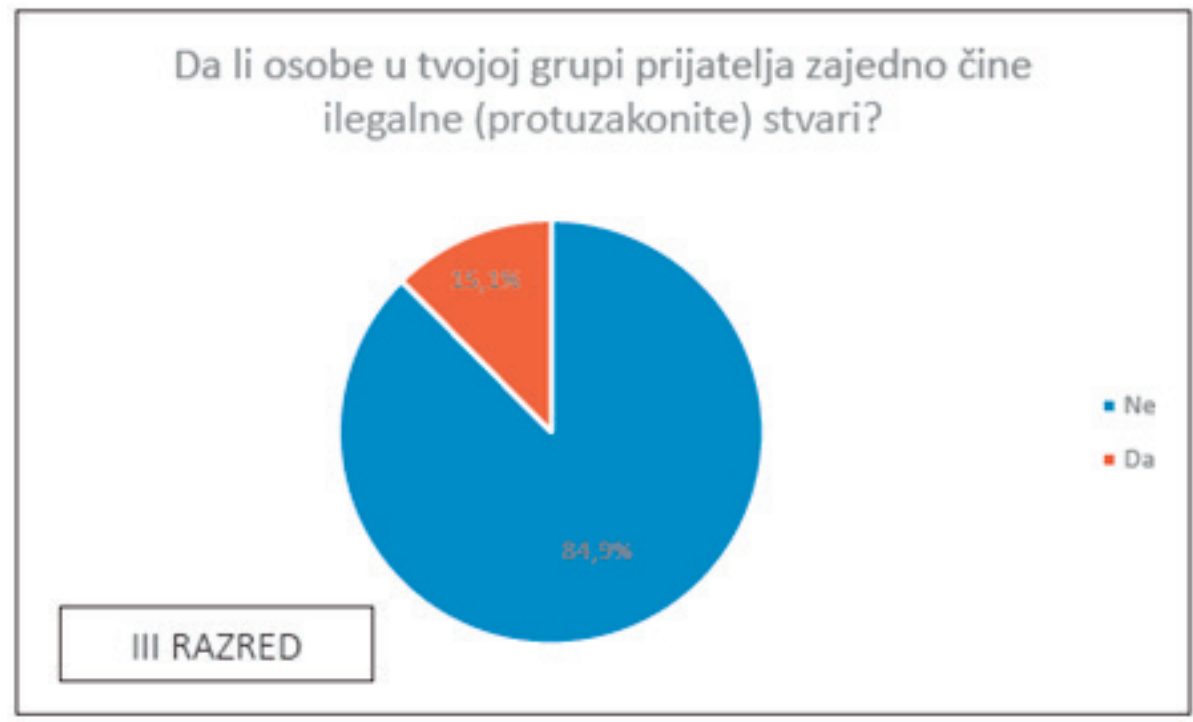

There is a very small percentage (5.8\%) of third-grade students who have had contact with the police because they have done something illegal. Consumption or "trying" of cannabis is low (cannabis - 17.8\%, ecstasy - 4,1\%), while consuming or "trying" alcoholic beverages is much higher (55.4\%).

In 13\% of cases, the third-grade students stated that they were mocked or severely teased in a harmful way in the social networks they use.

\subsection{Students' awareness of the feeling of safety in school and the prevalence of forms of sources of vulnerability and violence for fourth-year high school students}

When it comes to the results of the survey for the third-grade students, it is important to note that a total of 116 students participated in the survey. Out of the total number, 60 male students and 56 female students took part. The age structure of the respondents is such that 103 respondents are 18 and 13 respondents are 19 years old. In the block of questions about the upbringing aspect, the summarized data shows that in $86.5 \%$ (96 respondents) of cases, both parents participate in the upbringing of students. It is apparent that the socioeconomic situation shows a relatively large percentage of employed parents (fathers $75.2 \%$ - 85 and mothers $58.4 \%$ - 66). When asked "Where does your family income come from (money)", 93.6\% of the respondents answered that salary, earnings or property is a typical source of income. Fourthgrade students, when asked about the comparison of their financial situation with other families, in $61.6 \%$ of cases answered that they are in a similar financial situation as others, while $37.1 \%$ 


\section{Security}

of respondents considered to be in a better financial situation than others. The fact that $55.8 \%$ of students dine with their parents daily confirms strong family ties and cohesiveness between young people and parents/guardians. $8 \%$ of participants stated that they never have dinner with their parents/guardians.

It is interesting that $66.1 \%$ of young people estimate that they have an above average grade point average. There is a slightly higher percentage of absenteeism of least one full day in the last 12 months, which is shown by the $39 \%$ of the responses of fourth-year high school students. Four respondents from the entire sample for the fourth grade of high schools repeated the grade. Chart 20. shows the future of the youth. $79.3 \%$ of young people are already thinking about college after graduating from high school, while only $9 \%$ of young people are considering immediate employment.

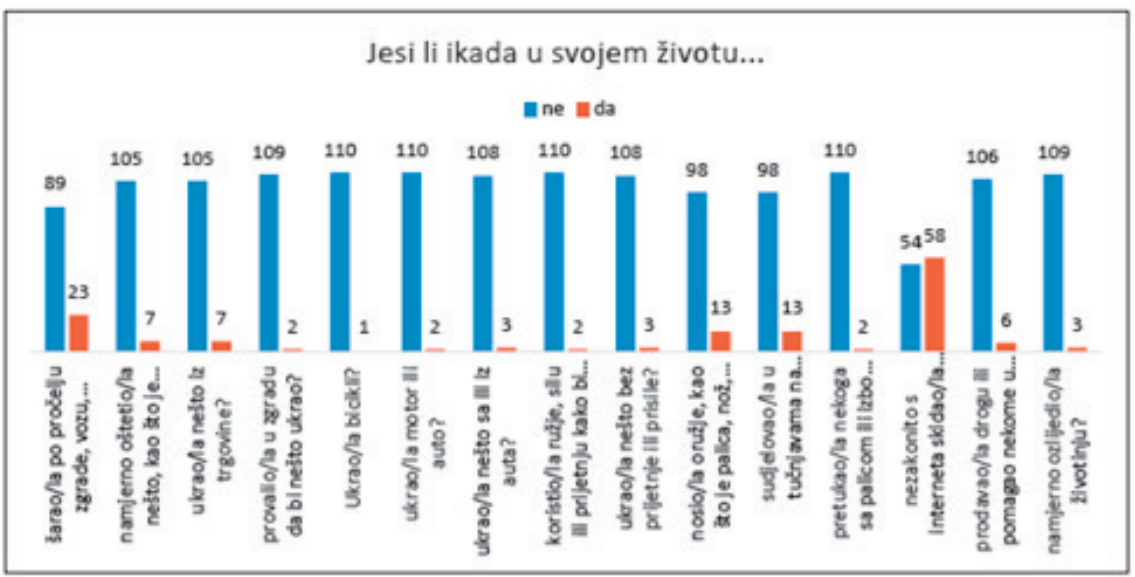

Grafikon 125

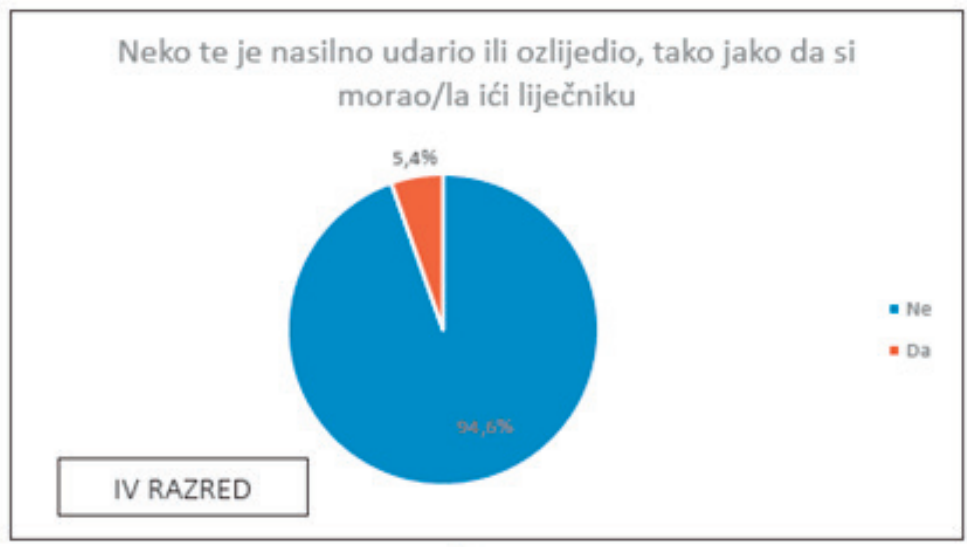

Grafikon 126 


\section{Security}

In the questions about school, students' perceptions of potential sources of vulnerability arising from (inadequate) conditions for the education process in and around the school (both the teaching process and school and yard infrastructure) were explored. Charts 21 and 22 are the focus of research attention, as it is noticeable that students were more explicit in answering questions about parts of school infrastructure and physical violence, which confirms that the sources of vulnerability to infrastructure and peer violence are represented to some extent in these schools. When it comes to claims regarding the school's infrastructure, condition, and equipment, it can be concluded that $48.6 \%$ of the students showed a negative opinion regarding the state of things in the school they go to. $38 \%$ of students said that drugs are used frequently in their schools (Chart 21.).

Within the question of things that young people sometimes do, it is interesting that, at the level of the whole sample, 98 participants state that they do not carry any weapons (bats, knives, guns or chains), while 13 respondents stated that they carry some of the following types of weapons (a stick, a knife, a gun or a chain) which can serve as a means of self-defense.

The next question concerned personal involvement in a fight as a physical form of violence. At the overall sample level, $88.4 \%$ of respondents stated that they had never participated in a fight. In fights at sports stadiums, streets or other public places, according to the survey, 13 respondents actively participated in such situations. Civen that the questioning was anonymous, but in direct contact with the interviewer, it is possible that these figures are higher. Also, in the section dealing with youth behavior, 23 students were involved in vandalising buildings and building entryways, while illegal downloading off the internet is reported by almost $65 \%$ of the fourth-grade students surveyed.

When asked "Has anyone hit you or hurt you so badly that you had to see a doctor?" six students answered yes (Chart 22.). Six students answered in the affirmative when asked about having to give money or other valuable items when threatened.

Regarding physical punishment by parents as a measure of sanction, results show that $36.9 \%$ of respondents were in the situation of being hit, slapped or pushed by their mother or father, while $17.3 \%$ of respondents were exposed to a severe form of punishment ("hit with an object, leg, fist or beaten").

In the block of questions concerning deviant and illicit behavior, there are noticeable behaviors that are punishable under $\mathrm{BiH}$ misdemeanor and criminal laws. According to the data, every fourth student says that something of theirs has been stolen (book, money, cellphone, sports equipment, bicycle, or something else).

Furthermore, the results of the survey show that $14.1 \%$ of students answered that stealing is frequent at their school. 24 of students stated that they had a friend who stole something from a store. More than half of the fourth-grade students said they had a friend who took light and heavy drugs, such as marijuana, hashish, ecstasy, speed, heroin or cocaine.

18 students said they have a friend who was beaten up or hurt with weapons such as a knife or bat. 


\section{Security}

$21.4 \%$ of the students surveyed said that they never go out in the evening, for example to a party, to hang out at someone else's house or hang out in the neighborhood, while $11.6 \%$ of the fourth-grade students surveyed said they go out for dinner every day, and $67 \%$ go out at least once a week.

The results regarding free time are shown in graph 23. The time that young people strive to fill with activities that are substantially different from the ones provided to them in school spaces is to some extent an act of courage or even progressive behavior. However, 17 students confirmed that they sometimes or often participate in fights with others, while 24 students confirmed that sometimes or often they "do something illegal for fun."

29 of the third-grade students said they "have fun scaring people and annoying them". Over $80 \%$ of students said that they study/do homework in their free time.

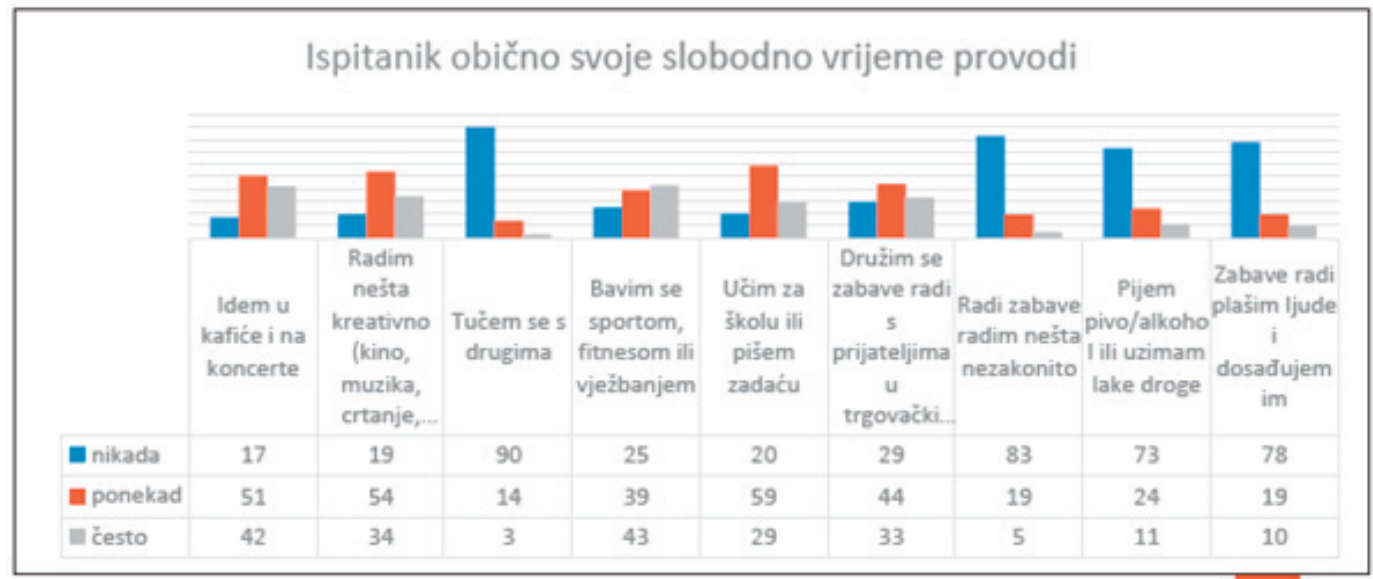

In the block of questions related to socializing with friends and forming a group, it is shown that $90.8 \%$ of fourth-grade students confirmed that they had a friend or a group of friends with whom they spend their free time, with whom they socialize and have fun. On the scale of responses in the "plenty" and "very much" intervals, a total of $85.6 \%$ of students answered that they would miss their friends if they had to move to another city.

It is important to note that $57.1 \%$ of respondents say that they spend time with friends in places such as parks, streets, shopping centers or neighborhoods. However, for $17 \%$ of young people, doing illegal things is acceptable to their group of friends, while $10.5 \%$ of the respondents said that people in their group do illegal things together. $7.5 \%$ of the students associate their group of friends with a gang.

There is a slightly larger percentage (12.6\%) of fourth-grade students who have had contact with the police because they have done something illegal. Every fourth student stated that they have tried cannabis, while only 3.6\% have tried ecstasy. Consuming or "trying" alcoholic beverages is much higher in the sample of fourth-grade students $(45 \%)$. 
Almost every fourth student stated that they were mocked or severely teased in a harmful way in the social networks they use.

\section{COMPARATIVE DIFFERENCE ANALYSIS}

Firstly, we will present some interesting attitudes of the first-grade high school students. A total of 90 first-grade students participated in the survey. It is interesting that $61.8 \%$ of first grade students are already considering college after graduating from high school, $4.5 \%$ of them are considering continuing their education through other forms of education, while $15.7 \%$ of young people are considering employment. When it comes to claims regarding the school's infrastructure, condition and equipment, $21 \%$ of students expressed a negative attitude towards the state of affairs in the school they attend. $15.7 \%$ of respondents stated that they carry one of these weapons (a stick, a knife, a gun or a chain), while $14 \%$ said that they sometimes or often "do something illegal for fun". The percentage of students (26\%) who "have fun scaring people and annoying them" is slightly higher. $35 \%$ of respondents say they will sometimes take the risk just for fun. Almost every sixth student confirms that they sometimes or often participate in fights with others (17\%). In $11.2 \%$ of cases, first grade students state that they have been mocked or severely teased in a harmful way in the social networks they use. When it comes to physical punishment by parents as a measure of sanction, $28.10 \%$ of respondents were in the situation of being hit, slapped or pushed by their mother or father, while $12.40 \%$ of respondents were exposed to more severe punishment. $28.8 \%$ of students said they had a friend who stole something from a store. $44.8 \%$ of students stated that they had a friend who took light and heavy drugs, such as marijuana, hashish, ecstasy, speed, heroin or cocaine. There is a very small percentage (6.7\%) of first grade students who have had contact with the police because they have done something illegal. Consumption of or "trying" light drugs is at a very low level (cannabis - $6.8 \%$ and ecstasy - 3.4\%), while consumption of alcoholic beverages is at a much higher level (38.6\%). When asked "Has someone hit you or hurt you so badly that you had to go to the doctor?" four students answered in the affirmative. The same number of answers was given to a question related to money or other valuable items being asked for in a threatening manner.

What follows is a more detailed presentation of the results of the research regarding certain attitudes of first grade students of secondary schools in the Sarajevo Canton, categorized by the schools that took part in the project activities. Namely, when it comes to the first grades, a total of 19 first grade students were questioned at the "Obala high school". All 19 respondents disagree with the statement that stealing is frequent at the "Obala high school". One respondent agrees that there is often a fight at the given school. Nine respondents agree with the claim that many things were broken or damaged in the school. One respondent stated that he was carrying a weapon (a stick, a knife, a gun or a chain). A total of 25 first grade students were interviewed at the High School for Environment and Wood Design. Eight respondents agree that stealing is frequent at the High School for Environment and Wood Design. Seven respondents agree with the statement that there is often a fight at the given school. Six respondents agree with the claim that many items were broken or damaged in the school. Four respondents report- 
ed carrying a weapon (a stick, a knife, a gun or a chain). A total of 22 first grade students were interviewed at Fifth High School. Only one out of 22 respondents agrees with the statement that stealing is freqent at the Fifth high school. One respondent agrees that this is often a fight. One respondent agrees that many things were broken or damaged at the school. Six respondents reported carrying a weapon (a stick, a knife, a gun or a chain). A total of 17 first-grade students were interviewed at Fourth High School. Two respondents agree with the statement that stealing is frequent at the Fourth Grammar School. One respondent agrees that there is often a fight at the Fourth High school. Four respondents agree that many things were broken or damaged at the given school. Three respondents stated that they carried some kind of weapon (a stick, a knife, a gun or a chain). A total of 7 first-grade students were surveyed at the "Technical High School of Graphic Technology, Design and Multimedia". All seven respondents disagree with the statement that stealing is frequent at the "High Tech School of Graphic Technology, Design and Multimedia". Two respondents agree that there is often a fight. Four respondents agree that many things were broken or damaged in the school. Two respondents stated that they carried some kind of weapon (a stick, a knife, a gun or a chain). A slightly higher number of first-grade students' responses was noted regarding the issues of "theft" and "brawl" at "High School for Environment and Wood Design", while students in other schools answered almost unanimously negatively that stealing is frequent at their school and that fights are a common occurrence. There is a slightly higher number of students at Obala High School and the Secondary Technical School of Graphic Technology, Design and Multimedia who agree with the claim that many things have been broken or damaged in the school they attend. A slightly higher number of first grade students in Fifth High School statie that they carry a weapon (a stick, a knife, a gun or a chain).

Next we will present some interesting attitudes of second-grade students of high school. A total of 92 second-grade students participated in the survey. $79.1 \%$ of second-grade students are considering college after high school, while only $3.3 \%$ of them are considering employment. $40 \%$ of students agreed that many things in their school were damaged or broken. $5.5 \%$ of respondents say they carry one of the following types of weapon (a stick, knife, gun or chain). $11.9 \%$ of students confirm that they sometimes or often participate in fights with others. In $13.2 \%$ of cases, second-grade students stated that they were mocked or severely teased in a harmful way in the social networks they use. 30.8\% of the respondents were in the situation of being hit, slapped or pushed by their mother or father, while $11 \%$ of respondents were exposed to severe punishment ("hit with an object, leg, fist or beaten"). $15.4 \%$ of students in the second grade of high school confirm that something has been stolen (book, money, cell phone, sports equipment, bike, or something else). $17.7 \%$ of students said they had a friend who stole something from the store. 37.5\% of students stated that they had a friend who took light or heavy drugs, such as marijuana, hashish, ecstasy, speed, heroin or cocaine. $6.5 \%$ of second-grade high school students responded that they had contact with the police because they committed something illegal. Consumption of or "trying" cannabis is low (12\%), while consuming or "trying" alcoholic beverages is much higher (46.7\%). When asked "Has anyone hit you or hurt you so badly that you 
had to go to the doctor?" three students answered yes. One student answered in the affirmative when asked about if they were threatened and asked to give money or other valuable items.

Furthermore, we will present certain attitudes of third-grade high school students. A total of 104 third-grade students participated in the survey. $73.8 \%$ of third grade students consider college after high school, while $12.6 \%$ of young people think about consider employment. $9.7 \%$ of respondents stated that they carry one of the following types of weapons (stick, knife, gun or chain). $17 \%$ of students confirm that they sometimes or often participate in fights with others. In $13 \%$ of cases, third-grade high school respondents stated that they were mocked or severely teased in a harmful way in the social networks they use. $31 \%$ of respondents were in the situation of being hit, slapped or pushed by their mother or father, while $10 \%$ of respondents were exposed to severe punishment ("hit with an object, leg, fist or beaten"). It is evident that almost every fifth student agrees with the claim that something was stolen from them at school (book, money, cell phone, sports equipment, bicycle, or something else). $21 \%$ of students said they had a friend who stole something from the store. $42.7 \%$ of students stated that they had a friend who took light or heavy drugs, such as marijuana, hashish, ecstasy, speed, heroin or cocaine. There is a small percentage (5.8\%) of third-grade students who have had contact with the police because they committed something illegal. Consumption or "trying" of light drugs is low (cannabis - $17.8 \%$ and ecstasy - $4.1 \%$ ), while alcohol consumption is much higher (55.4\%).

When asked "Has anyone hit you or hurt you so badly that you had to go to the doctor?" three students answered yes. A third grade student answered yes to being asked for money or valuable items after being threatened.

Finally, we will present the attitudes of fourth-grade high school students. A total of 116 fourth-grade students participated in the survey. In this section, it is important to point out that a large percentage of young people (79.3\%) are already considering college right after graduating from high school, while only $9 \%$ are considering employment. $48.6 \%$ of students showed a negative attitude towards the state of affairs at their school. 13 respondents, or $11.7 \%$, stated that they carried one of these weapons (a stick, a knife, a gun or a chain). $19.6 \%$ of fourth-grade high school students say that they have been mocked or seriously teased in a harmful way in the networks they use. 36.9\% of the respondents were in the situation of being hit, slapped or pushed by their mother or father, while $17.3 \%$ of respondents were exposed to severe punishment ("hit with an object, foot, fist or beaten"). It is evident that $27.7 \%$ of fourth grade students claim that something was stolen (book, money, cellphone, sports equipment, bike, or something else). $21.6 \%$ of students said they had a friend who stole something from the store. Slightly more than half of the fourth grade students have friends who have taken light or heavy drugs, such as marijuana, hashish, ecstasy, speed, heroin or cocaine. $16.2 \%$ of students responded that they had a friend who beat or badly injured someone with a weapon such as a knife or a stick. 15.9\% of students confirm that they sometimes or often participate in fights with others. A slightly higher percentage $(12.6 \%)$ of fourth-grade students had contact with the police because they committed something illegal. Almost one in four students claims to having used cannabis, while consuming or "trying" Ecstasy is very low (3.6\%). However, consuming or "trying" alcoholic bev- 


\section{Security}

erages is at a much higher level of representation among the population of fourth-grade high school students (45\%). When asked, "Has anyone hit you or hurt you so badly that you had to go to the doctor?" six students answered in the affirmative. The same number answered in the affirmative when asked if they were threatened by someone to hand over money or valuable items.

\section{CONCLUSION}

The purpose of this research was to investigate students' sense of security in and around high schools in the Sarajevo Canton. Our schools are not alone in dealing with the problem of child safety, and this is reflected in research conducted in other countries of the world. This research points out that the percentage of school children who are victims of violence in most countries is similar; that professors and teachers ignore or take concrete steps to prevent bullying and intimidation at school; that aggressive behavior is learned early and difficult to change. The many shortcomings, failures and challenges of school safety show us that, as a society, we are not sufficiently concerned with the safe, or at least safer, schools. Identifying potential risks to students and eliminating them in a timely manner will certainly help not only students, but our society as a whole.

Certain studies conducted in 2018 in the Sarajevo Canton, conducted by the Faculty of Criminology, Criminology and Security Studies at the University of Sarajevo, have pointed to the increasing occurrence of juvenile delinquency, which is also manifested through violence in schools. Based on a survey of 271 students in grades 4 through 8 , or $52.78 \%$ of the total number of students of that age, it was reported that in Sarajevo elementary schools, 37.45\% of students experience some form of violence every day, while being violent towards others was done by $73.46 \%$ of students. According to this research, the most common forms of school violence are: pushing $-36.11 \%$, hitting $-25 \%$, ridicule $-22.22 \%$, exclusion $-20.83 \%$, derogatory names $-19.44 \%$, destruction of personal belongings $-15.28 \%$, telling rumors $-13.89 \%$, taking money forcefully - 11.11\% (Ahić, Korajlić, \& Hadžikadunić, 2018). It is interesting that, for example, the area of the Una-Sana Canton is included in the context of the problems and challenges that young people face in educational institutions on a daily basis. Seventh and eighth-grade students, 163 of them, are the most apprehensive about possible peer violence, and $38.5 \%$ said they had a fight at their schools. $51.1 \%$ of parents of students are concerned about school and schoolyard safety. Stray dogs (27.6\%), traffic neglect (23.2\%) and other abusive children (15.5\%) are the greatest sources of danger for children in and around school. The percentage of unpleasant situations in respondents (students) related to threats about their cellphone, watch or other (1.2\%) is almost insignificant, while theft is represented in 28.3\% (Ahić et al., 2019 ).

The results of the study show that when asked "Have you been hit or hurt so badly that you had to go to a doctor?" 16 of 402 students answered yes. We would like to remind you that a total of 90 first grade students, 92 second grade students, 104 third grade students and 116 fourth grade high school students in the Sarajevo Canton participated in the survey. The issue of the situation in and around the school is of paramount importance in fulfilling the defined contribution of the research carried out, which aims to improve policies and create a unique 
platform for further improving youth safety in the Sarajevo Canton. In this regard, $21 \%$ of firstgrade students, $40 \%$ of second-grade students, $57.3 \%$ of third-grade students and $48.6 \%$ of high school graduates expressed a negative attitude towards the state of affairs at school. $15.7 \%$ of first grade students, $5.5 \%$ of second grade students, $9.7 \%$ of third grade students and $11.7 \%$ of fourth grade students say they carry one of the following types of weapons (bat, knife, gun or chain).

$11.2 \%$ of first-grade students, $13.2 \%$ of second-grade students, $13 \%$ of third-grade students and $19.6 \%$ of high school fourth-graders said they were mocked or severely teased in a harmful way through the social networks that they use. $17 \%$ of first grade students, $11.9 \%$ of second grade students, $17 \%$ of third grade students and $15.9 \%$ of fourth grade students confirm that they sometimes or often participate in fights with others. $28.8 \%$ of first grade students, $17.7 \%$ of second grade students, $21 \%$ of third grade students and $21.6 \%$ of fourth grade students stated that they had a friend who stole something from a store. $6.7 \%$ of first grade students, $6.5 \%$ of second grade students, $5.8 \%$ of third grade students and $12.6 \%$ of fourth grade students responded that they had contact with the police because they did something illegal.

According to Olweus et al. (1999) preventive steps in violence and creating a positive environment in schools must include students, parents and the school staff. This is often manifested in an anti-bullying context, and emphasizing an inclusive approach to problems (Olweus, Limber, $\&$ Mihalic, 1999). In order to achieve overall success, treatment and prevention efforts should, to a greater extent, take the form of broad programs that seek to make use of the constructive institutional and human resources more effective and available in each local community in the city. Prevention of juvenile delinquency is a system of measures and activities aimed at eliminating all immediate, objective and subjective conditions and circumstances conducive to the emergence and the practice of crime. Such measures are taken by all state and social bodies, social organizations and institutions, ranging from family, school, social protection, to representative bodies of all socio-political communities. The importance of the role of the school in the upbringing and education of children is immediately after the family, but the family does not have the necessary conditions for organizing a variety of activities for their children. Parents often lack the necessary knowledge and skills. In addition to family and school, the role of the local community in ensuring the conditions for an active and high-quality organization and the leisure of children is also very important. In order to fulfill its role for the benefit of children, the local community must provide space, staff and other conditions for quality leisure and activities for children.

In order to carry out quality prevention and intervention programs for youth violence, it is important to know and understand the characteristics of the observed developmental age, as well as the causes of violent behaviors of young people. It is crucial to understand just how safe, or unsafe, young people are in their environment. Within the mosaic of risk and protective factors affecting young people, it is primarily appropriate and timely to identify the current spectrum of factors and their relationships, to analyze and determine the intensity of their action, 


\section{Secuurity}

because as such they are a prerequisite for effective prevention plans and strategies, as well as for the treatment of behavioral disorders.

\section{LITERATURE}

Ahić, J., Hadžikadunić, A., Budimlić, J., Halilović-Kibrić, N., Hodžić, K., Cucak, A. (2019). Sigurnost u odgojno-obrazovnim ustanovama na području Unsko-sanskog kantona. Sarajevo: Fakultet za kriminalistiku, kriminologiju i sigurnosne studije.

Ahić, J., Korajlić, N., \& Hadžikadunić, A. (2018). Sigurnost u odgojno-obrazovnim ustanovama na području Kantona Sarajevo. Sarajevo: Fakultet za kriminalistiku, kriminologiju i sigurnosne studije.

Arriagada, I. and Godoy, L. (2000). Prevention or repression? The false dilemma of citizen secutiry. Cepal Review, 70: 111-36.

Čurčić, S. (1992). Geografija naselja. Novi Sad: Univerzitet u Novom Sadu.

Fajnzylber, P., Lederman, D. and Loayza, N. (2002). What causes violent crime?. European Economic Review, 46(7), pp.1323-1357.

Fitzgerald, J. D., Fox, S. M., Bakić, I., \& Muratbegović, E. (2001). Metodologija istraživanja u kriminalističkim naukama. Sarajevo: Fakultet kriminalističkih nauka.

Hazler, R.J. (1996.). Breaking the cycle of violence: Interventions for bullying and victimization. Washington, DC: Accelerated Development.

Karlović, A. (2001). Validacija upitnika o zlostavljanju u djetinjstvu: Filozofski fakultet Sveučilišta u Zagrebu.

Larson, R., \& Verma, S. (1999). How Children and Adolescents Spend Time across the World: Work, Play and Developmental Opportunities. Psychological Bulletin, 125, 701-736.

Lavrakas, P. J. (1982). Fear of Crime and Behavioral Restrictions in Urban and Suburban Neighborhoods. Population and Environment, 5(4), 242-264.

Mcllwaine, C. (1999). Geography and development: violence and crime as development issues. Progress in Human Geography, 23(3), pp.453-463.

Meltzer, H., Panos, V., Goodman, R. i Tamsin, F. (2007.) Childrens' perceptions of neighbourhood trustworthiness and safety and their mental health. Journal of Child Psychology and Psychiatry, 48, 1208-1213

Nikčević-Milković, A. (2006). Nasilje među djecom u školi: postoje li razlike u zavičajnom, nacionalnom i globalnom kontekstu? Zavičajnost, globalizacija i škola: znanstveno-stručni skup s međunarodnim sudjelovanjem. Gospić: Visoka učiteljska škola u Gospiću, Sveučilište u Rijeci.

Olweus, D., Limber, S., \& Mihalic, S. (1999). Blueprints for Violence Prevention. Colorado: Institute of Behavioral Science, University of Colorado Boulder.

Osher, D., Kendziora, K., Spier, E. i Garibaldi, M. L. (2014). School influences on child and youth development. U: Sloboda, Z. i Petras, H.: Defining Prevention Science, 151-169. New York: Springer US.

Pedagoški zavod Kantona Sarajevo, http://portal.skola.ba/ppzsa/Obrazovneustanove/Srednje\%C5\%Alkole/tabid/129/Default.aspx (mart 7, 2019). 
Poredoš Lavor, D., Lavor, T., Valentić, A., Velešnjak, S., Dasović, A., Preporučeni, I., \& Koić, E. (2010). Prikaz razloga nasilja među djecom iz perspektivne djece u dobi od 8 do 11 godina života. Zbornik radova sa skupa "Nasilje nad djecom i među djecom 2008". Osijek: Sveučilište Josipa Jurja Strossmayera u Osijeku.

Stahura, J., \& Sloan III, J. J. (1988). Urban Stratification of Places, Routine Activities and Suburban Crime Rates. Social Forces, 66 (4), 1102-1118.

Šimić, N. (2004). Doprinos istraživanja pojavnosti nasilja među djecom u školi: diplomski rad. Filozofski fakultet Sveučilišta u Zagreb, Zagreb.

Tilleczek, K. i Ferguson, B. (2007). Transitions and Pathways from Elementary to Secondary School: A Review of Selected Literature. Toronto: Ontario Ministry of Education.

Vizek Vidović, V., Rijavec, M., Vlahović-Štetić, V., Miljković, D. (2003). Psihologija obrazovanja, IEP, Zagreb.

Wood, L., Shannon, T., Bulsara, M., Pikora, T., McCormack, G., \& Giles-Corti, B. (2008). The anatomy of the safe and social suburb: An exploratory study of the built environment, social capital and residents perceptions of safety. Health \& Place, 14, 15-31.

Zani, B., Cicognani, E. i Albanesi, C. (2001.) Adolescents' sense of community and feeling

Zloković, J. (2004). Nasilje među vršnjacima - problem obitelji, škole, društva. Pedagogijska istraživanja, Vol.1, No.2, str. 207-219. 